\title{
What about Mom? The Forgotten Beneficiary of the Medicaid Expansions*
}

\author{
Andrea Kutinova** \\ Department of Economics \\ University of Canterbury \\ Private Bag 4800 \\ Christchurch, New Zealand \\ Phone: (+64-3) 364-2823 \\ E-mail: andrea.kutinova@canterbury.ac.nz \\ and \\ Karen Smith Conway \\ Department of Economics \\ University of New Hampshire \\ McConnell Hall \\ Durham, NH 03824, USA \\ Phone: (+1-603) 862-3386 \\ E-mail: ksconway@unh.edu
}

Running head: Medicaid Expansions and Maternal Health

JEL code: I18

* We thank Reagan Baughman, Marianne Bitler, Pinka Chatterji, Partha Deb, Sarah Laditka, Robert Mohr, and Robert Woodward for their invaluable suggestions. This paper has also greatly benefited from comments received at the Eastern Economic Association, AcademyHealth, and Southern Economic Association meetings, and the University of New Hampshire economics seminar.

** Corresponding author: Department of Economics, University of Canterbury, Private Bag 4800, Christchurch, New Zealand; Phone: (+64-3) 364-2823, E-mail:

andrea.kutinova@canterbury.ac.nz. 


\begin{abstract}
This paper contributes to evidence regarding the effectiveness of the Medicaid expansions by focusing on a key beneficiary - the mother - who has previously been overlooked. Using the Natality Detail Files for 1989-96, we estimate the relationship between Medicaid eligibility and maternal health outcomes for several treatment groups and a control group. Potential biases caused by improved reporting are addressed by using a 'straw man' maternal complication not preventable with prenatal care. Our results suggest that increased Medicaid eligibility may have led to fewer preventable maternal complications among women most likely to have benefited from the Medicaid expansions.
\end{abstract}

Keywords: Maternal health, Medicaid, Prenatal care 


\section{Introduction}

In the late 1980's and early 1990's, the Medicaid eligibility rules changed substantially. The income thresholds increased and individuals in two-parent families started to qualify. By providing health insurance coverage to all low-income pregnant women and their children, the policymakers hoped to achieve their ultimate goal: improve health outcomes. Have they succeeded? Trying to answer this question, several studies have investigated the effects of the expansions on infant health (Currie and Gruber 1996a, 1997; Dubay et al. 2001; Currie and Grogger 2002) and a few studies have focused on the effects on child health (Currie and Gruber 1996b; Kaestner et al. 2001). So far, the results have been mixed, leading to a general skepticism about the effectiveness of the Medicaid eligibility expansions in improving health.

We argue, however, that an important potential beneficiary of the expansions - the mother - has been left completely out of the analysis. To our knowledge, no economic study has investigated the effects of the policy changes of the 1980's and 1990's on maternal health. However, pregnant women have always been a key target population of the Medicaid program. Therefore, without estimating the impacts of the expansions on maternal health (in addition to infant health and child health), any evaluation of the effectiveness of the policy is incomplete. In this paper, we attempt to close the gap. In particular, using the Natality Detail Files for 19891996, we estimate the relationship between Medicaid eligibility and maternal health outcomes for several treatment groups and a control group. Our results suggest that increased Medicaid eligibility may have led to fewer preventable maternal complications among women most likely to have benefited from the expansions. 


\section{Background}

Is maternal health an issue in a developed country such as the U.S.? We believe that it is. As Haas et al. (1993) note in their study: "Although only 10 per 100,000 women die from a complication of pregnancy or childbirth, $60 \%$ of women receive medical care for some complication of pregnancy, and 30\% suffer complications that result in serious morbidity."(p.61) An interest in the issues surrounding maternity in the U.S. is finally awakening among applied economists; for instance, Chatterji and Markowitz (2005) estimate the impacts of the length of maternity leave on maternal depression and women's 'overall health' (number of outpatient visits) postpartum. The importance of maternal health has also repeatedly been recognized in national health guidelines - most recently the Healthy People $2010^{1}$ (Public Health Service 2000). Also, the Medicaid program itself has been designed to help disadvantaged pregnant women and their infants and children.

It is therefore surprising to find that the direct health effects of policies targeted at disadvantaged women in the U.S. have largely been overlooked in the economics literature. After ten years, an observation made by Jennifer Haas and her coauthors (Haas et al. 1993) remains valid: "Although there has been substantial policy interest in interventions to improve the neonatal outcomes of disadvantaged women, little attention has been paid to the health status of pregnant women themselves." (p.61) As previous research suggests, this is an important oversight. Haas et al. (1993) show that women who receive 'satisfactory' prenatal care have better health outcomes (as measured by the occurrence of severe pregnancy-related hypertension, placental abruption, or mother's stay in hospital after delivery at least one day longer than her infant's stay) than women who receive 'inadequate' prenatal care, and Conway and Kutinova (2006) demonstrate that timely and adequate prenatal care may increase the probability of 
maintaining a healthy weight after the birth. This suggests that policies designed to improve prenatal care access may indeed benefit the mothers themselves.

\section{Past Research on Policies’ Impacts on Maternal Health}

We are aware of only one recent economic policy-oriented study that focuses on the health status of disadvantaged women in the U.S.: Kaestner and Tarlov (2003) investigate the effects of the welfare contractions of the 1990's on women's health (overall health status and mental health) and health behaviors (smoking, drinking, and exercise). In particular, the authors hypothesize that the welfare changes were likely to affect the 'employment stress,' 'organizational stress,' and 'financial stress' faced by low-income women and thus might have indirectly affected the health status of these women. While the Kaestner and Tarlov (2003) study certainly represents an important contribution to the health economics literature, it does not fill the gap identified above. First, the authors focus on the general health of a disadvantaged population rather than studying the particular health complications women may encounter due to pregnancy and/or maternity. Second, the study deals with an indirect impact of a general welfare program on health outcomes and behaviors rather than estimating the effects of a policy - such as Medicaid - designed primarily to improve the health status of its target population.

Bitler and Currie (2005) somewhat closes these gaps by including maternal health outcomes (maternal weight gain and nights hospitalized pre- and at-delivery) in their study of the effectiveness of WIC (the Special Supplemental Nutrition Program for Women, Infants and Children) on birth outcomes. However, the program they study has more of an indirect impact on maternal health, and the authors' primary focus is on infant health outcomes. Still, their finding that WIC increases maternal weight gain and may reduce maternal hospitalization at delivery 
(Table 3, p.84) is suggestive for our research here. First, it demonstrates that nutritional policies may benefit the mother's health during pregnancy as well as the infant's; improved nutrition is certainly one goal of prenatal care. Second, as discussed later, expanding Medicaid eligibility may result in expanded eligibility for WIC through its adjunctive eligibility (Lewis and Ellwood, 1999). It is therefore possible that the estimated effects of Medicaid on maternal, infant, and child outcomes may include the indirect effects of increased WIC participation. For this reason, we investigate whether the most obvious direct avenue for Medicaid to have an effect improved prenatal care - is evident as well.

To our knowledge, there are only two economic studies of health policies in the U.S. that include the expectant mother - Currie and Gruber $(1997,2001)$. However, these studies focus on the effects public insurance has on the medical treatments and procedures provided to the mother (i.e., cesarean section delivery, use of a fetal monitor, receipt of ultrasound and induction/stimulation of labor). They do not estimate any impact on maternal health outcomes. A similar and more recent study - Busch and Duchovny (2005) - estimates the effects of postPRWORA Medicaid expansions to low-income parents on health insurance coverage and health care utilization (cancer screening and forgoing medical care due to cost) among adults. However, this study excludes pregnant women and does not consider the effects on health outcomes. Whether Medicaid (or other health care policies) benefits the mother thus remains an open question.

\section{Measuring Maternal Health}

Due to the lack of research in the area, there is not a generally recognized measure of maternal health (an analog to birth weight in infant health studies). Facing this problem in our 
current study, we have decided to focus on the incidence of three complications to maternal health identified in the medical literature as potentially preventable by prenatal care: placental abruption, pregnancy-associated hypertension, and anemia. In addition, due to the infrequency of these events, we have also employed a summary indicator of maternal health capturing the presence of any of the three complications mentioned above. All of our measures of maternal health can be derived using the information available in vital statistics.

Placental abruption ${ }^{2}$ and pregnancy-associated hypertension ${ }^{3}$ are identified in Haas et al. (1993) as important causes of maternal morbidity that can be prevented by interventions during the prenatal period. About placental abruption, Haas et al. (1993) write: "Since placental abruption may be associated with poorly controlled hypertension and maternal smoking, this condition may $[\ldots]$ be preventable with prenatal intervention." (p.62) With respect to hypertension, the Healthy People 2010 stress the need for timely and high-quality prenatal care which would "improve maternal health by identifying women who are at particularly high risk and taking steps to mitigate risks, such as the risk of high blood pressure [...]" (Public Health Service 2000, p.16-8) In the public health literature, the role of comprehensive prenatal care in preventing and managing hypertension has long been recognized (Lopez-Jarmillo et al. 2005, Scholl et al. 1994, Sachs et al. 1988). According to Lopez-Jarmillo et al. (2005), prenatal care providers can prevent pregnancy-related hypertension by administering calcium supplements and treating vaginal and urinary infections among women at high risk.

As for anemia, ${ }^{4}$ several recent medical papers have investigated the options for preventing the occurrence of this complication in pregnant women and have concluded that adequate iron therapy during the prenatal period can be very effective (Bashiri et al. 2003, Makrides et al. 2003, Villar et al. 2003). The Healthy People 2010 recommendations urge to 
"reduce anemia among low-income pregnant females in their third trimester" and to "reduce iron deficiency among pregnant females." (Public Health Service 2000, Objectives 19-13 and 19-14, respectively) Laditka et al. $(2005,2006)$ who have constructed an index of potentially avoidable maternity complications (PAMCs) stress the role of prenatal care in preventing and treating anemia. Therefore, if the Medicaid expansions increased the health insurance coverage of lowincome pregnant women and improved their access to prenatal care, our four measures (including the summary indicator) should be able to capture the potential positive impact of the expansions on maternal health.

Furthermore, these potentially avoidable maternal complications are not rare events. As a CDC report notes, anemia and hypertension were among the most common complications of pregnancy in the 1990's (CDC 2001). In the year 1999, for example, 2.32 and 3.82 percent of pregnant women suffered from anemia and pregnancy-associated hypertension, respectively. Placental abruption occurs less frequently ( 0.6 percent of pregnant women had it in the year 1999) but its consequences are more severe.

Preventing maternal complications such as anemia, hypertension, and placental abruption can lead to improvements in the quality of life as well as to substantial cost savings. In the year 1997, for example, pregnancy-related hypertension and anemia were among the top 100 primary diagnoses associated with the highest national expenditures for hospital stays; the costs of 'hypertension complicating pregnancy, childbirth and the puerperium' were over $\$ 1.2$ billion and the costs of anemia (pregnancy-related or other) over $\$ 962$ million. For purposes of comparison, the national charges for hospital stays due to 'short gestation, low birth weight, and fetal growth retardation' were about $\$ 1.1$ billion in the year 1997 (Geocities 2004). Estimates of the overall annual costs of 'hypertensive disorders of pregnancy' for the year 2003 exceed \$3 billion 
(Preeclampsia Foundation 2004). Placental abruption is a rarer - but still costly - morbidity. In the year 1996, for example, the annual national costs of hospitalizations due to placental abruption were $\$ 156$ million (AHRQ 1996). These numbers further highlight the fact that maternal health - and the specific measures we have chosen to study - is an important issue.

\section{Empirical Strategy and Data}

The two major changes to the Medicaid policy in the late 1980's and early 1990's were a dramatic increase in the income cutoff below which women qualified for Medicaid and an extension of Medicaid eligibility to married women. The federal government has played a key role in initiating these changes. By April 1990, all states were required to offer Medicaid coverage to pregnant women with incomes below $133 \%$ of the federal poverty line.

However, the states were given some freedom in designing their Medicaid programs. For example, states could increase the eligibility threshold for pregnant women up to $185 \%$ of the poverty line and still qualify for subsidies from the federal government. It is also important to note that the states started from very different positions with initial eligibility ranging from $34 \%$ (Louisiana) to $185 \%$ (Massachusetts, Minnesota, Mississippi, and Vermont) of the federal poverty line in 1988. As a result, while the increase in Medicaid eligibility in the early 1990's was a nation-wide phenomenon, the states differed with respect to the magnitude of the increase. Also, the timing of the changes varied widely across states. Figure 1 shows how the minimum, maximum, and average eligibility cutoffs changed over time, and Figure 2 shows how the eligibility rules differed across the five largest U.S. states. This variability allows us to study the effects of the Medicaid eligibility increases on utilization of prenatal care and the associated maternal health improvements while controlling for state heterogeneity in unobservable 
characteristics as well as a national time trend. We further refine our analysis by identifying groups which were most and least likely to be 'treated' by the policy expansions and employing a 'difference-in-differences' empirical approach.

\section{Identifying Treatment and Control Groups}

Mothers with low socioeconomic status (SES) were most likely to be affected by the Medicaid policy changes. Many of these women did not qualify for Medicaid before the reforms (either because they had incomes above the cutoff or because they were married) but gained their eligibility in the early 1990's. High SES women, on the other hand, are unlikely to benefit from the reforms because their incomes are too high. This variability in the likely effects of the Medicaid eligibility expansions across individuals allows us to further identify the causality of the relationship between the expansions and prenatal care utilization and health outcomes. In particular, we adopt a difference-in-differences type of approach and compare the effects of the policy changes among members of several treatment groups - low SES married and single mothers - and a control group - high SES married women. ${ }^{5}$ If Medicaid did help its target population, we would expect to find a significant effect of the expansions on women in the treatment groups but an insignificant effect on women in the control group.

Furthermore, we hypothesize that very-low SES pregnant women benefited from the expansions the most. As previous studies have found, the eligibility expansions were most likely to lead to insurance coverage increases (high take-up rate, low crowd-out of private insurance), increases in the utilization of a variety of obstetric procedures, and infant health improvements among the lowest SES women (Currie and Gruber 1996a, 1997, 2001). Therefore, any improvements in maternal health attributable to the Medicaid eligibility expansions would likely 
be concentrated in the very-low SES cohort. Since married women might be more strongly affected by the eligibility changes than single mothers (many single women already qualified for Medicaid before the reforms) and since the two groups of women could also be differentially affected by the welfare declines of the early 1990's (only single women generally qualified for AFDC at that time ${ }^{6}$ ) we have decided to stratify our treatment population by marital status. The control group is selected to represent mothers least likely to benefit from the expansions (with high SES married women typically ineligible for means-tested public programs).

Our data (to be discussed shortly) do not include information on individual-level income or insurance status. Therefore, we follow earlier studies (e.g., Currie and Gruber 1997, 2001; Dubay et al. 2001; Currie and Grogger 2002; Kaestner and Kaushal 2004; Kaestner and Tarlov 2003; Joyce et al. 2003) and proxy for socioeconomic status with educational achievement. It is possible, however, that the lowest SES women (especially those unmarried) were eligible before the Medicaid expansions and therefore may not have been 'treated.' For this reason, we employ a more exhaustive list of possible treatment groups than most previous studies of the Medicaid expansions, which typically focus on teenaged, single and/or high school drop-outs as their treatment groups (e.g., Currie and Gruber 1997, 2001; Currie and Grogger 2002). Furthermore, as described below, we provide a supplementary analysis using the CPS to explore the validity of these groups. In this study, we assign women with less than 12 years of education ('less than high school'), 12 years of education ('high school completed'), and between 13 and 15 years of education ('some college') into three separate less educated/low SES cohorts and women with 16 or more years of education ('college completed') into the highly educated/high SES cohort. We then define four 'treatment groups': (1) married women with 'less than high school,' and (2)-(4) unmarried women with 'less than high school,' 'high school completed' and 'some college,' 
respectively. Our 'control group' consists of married women with 'college completed.' Women who cannot be clearly classified as either 'treated' or 'untreated' (such as married women with 'high school completed') are excluded from the analysis.

We therefore follow past literature that identifies groups of women most likely to have been 'treated' by the policy but does not observe whether these women actually became eligible and enrolled in the program. As such, our estimated treatment effects are interpreted as the effects of a change in the policy parameters (i.e., eligibility thresholds) rather than the actual effects of enrolling in Medicaid. This approach has the advantage that it investigates the effects of what policymakers have control over - the policy parameters - and that such parameters are exogenous to individual behavior (unlike the decision to enroll). On a practical level, we are forced to take this approach because our data contains no information about income or insurance status. However, it also means that we may find low treatment effects either because our identified treatment groups in reality did not experience large increases in eligibility or they had low 'take-up' (or high 'crowd-out') of the policy.

To explore the validity of our stratification and the likely extent of low take-up as a confounding factor, we provide a confirmatory, descriptive analysis that estimates how much our treatment groups actually increased their enrollment in Medicaid as a result of the policy change. In particular, we use 1989 and 1996 data from the Current Population Survey (CPS) to calculate cohort-specific 'enrollment treatment probabilities' according to the following formula:

$\operatorname{Prob}($ treatment $)=\operatorname{prob}($ covered by Medicaid in 1996 but not covered in 1989),

which we approximate with the following: $=\%$ covered by Medicaid in $1996-\%$ covered by Medicaid in 1989 . 
Prob(treatment) is one measure of the intensity of treatment. In a supplemental analysis, however, we move even closer to the ultimate impacts and construct a similar measure for the probability of 'any' health insurance coverage. This latter measure accounts for the possibility of crowd-out.

Due to the nature of the measures employed and the simplicity of our methodology, the CPS analysis should be viewed as illustrative only. It does reflect the impacts of the Medicaid expansions but fails to control for other confounding factors such as welfare changes, the cost of health insurance premiums and the strength of the labor market. Earlier studies which use a multivariate framework to deal with these confounding factors suggest that the Medicaid expansions led to the largest insurance increases among low SES women (e.g., Currie and Gruber 1996a, Currie and Gruber 1997). In our econometric analysis of maternal health outcomes, discussed shortly, we also control for a variety of confounding factors, but to attempt to do so properly in the confirmatory analysis is beyond the scope of this paper. Another caveat is that our CPS analysis includes all women of childbearing age and therefore likely produces much smaller treatment probabilities than if the analysis was limited to pregnant women. ${ }^{7}$

Table 1 reports the enrollment treatment probabilities and their individual components for each race/education/marital status cohort. Despite the caveats, our first treatment group, married very low educated women, appears to be the most heavily 'treated' group in terms of increased Medicaid coverage among blacks (at 14.36 percentage points) and one of the most 'treated' among whites (at 6.94 points). More generally, the treatment and control groups we chose $a$ priori behave very well for our white cohorts. The four treatment groups experience the largest increases in Medicaid coverage of all the education/marital status groups possible in the data and 
our control group has the smallest increase. The treatment intensity also declines as the education levels grow within our treatment groups (especially for TR \#3 vs. \#4).

For black unmarried mothers, the analysis is less supportive. While all three treatment groups of unmarried mothers (\#2-4) experience small increases in Medicaid coverage, some other (neither treatment nor control) cohorts have larger increases. However, there is no clear pattern of treatment intensity among the cohorts that might suggest a change to our strategy and, at least, the control group experiences the smallest increase (largest decrease). Perhaps the confounding effects of welfare changes are more problematic for black unmarried mothers. Indeed, we find in the CPS data that unmarried black women with 'less than high school' education (TR \#2) experienced a decline in AFDC participation of about 11 percentage points in the studied period (in contrast to a modest increase in most other groups). ${ }^{8}$ Thus, Medicaid expansions above and beyond welfare had to be especially strong in this cohort in order to offset the negative effect of the AFDC contraction. Again, in our econometric analysis, we attempt to control for influences that affect AFDC participation. Another reason why the black treatment/control groups behave less satisfactorily could be the much smaller sample sizes of the black cohorts, which make the resulting estimates less reliable.

For the sake of completeness, the last three columns of Table 1 report the change in 'any' health insurance (HI; which includes Medicaid) coverage for each of the cohorts during the study period. All of the pitfalls of a confirmatory analysis are even more serious here as many factors beyond possible 'crowd-out' could influence HI coverage. The cohorts we expect to be most heavily treated - married, very low educated women - again behave reasonably well as both (especially blacks) experience increases. For the other cohorts, the results are much more mixed and again are especially disappointing for unmarried black women. 
Overall, the above findings are reasonably supportive of our selection of the treatment and control groups, especially with respect to Medicaid coverage and especially for married, very low educated women. Furthermore, as a recent paper (Lewbel, 2003) demonstrates, any misclassification into the treatment and/or control cohorts will bias the estimated treatment effects towards zero, making our results conservative. This also implies that if our empirical strategy for identifying treatment and control groups is less satisfactory for unmarried blacks, as suggested by this analysis, we should expect our empirical results for maternal health outcomes to be weaker as well. We return to this issue when we discuss the results of our econometric model in section 5 .

\section{Possible Reporting Error}

In addition to treatment misclassification, however, there is still a possible confounding factor in that improved prenatal care access (and by extension Medicaid) could lead to increased reporting of previously undetected maternal health complications and thus seemingly increase their prevalence. This reporting bias could cause further underestimation of the real (as opposed to observed) impact that the Medicaid expansions have had on maternal health. To deal with this issue, we use a 'straw man' complication against which we compare the results for our key measures of maternal health (placental abruption, anemia, and pregnancy-related hypertension). Unlike our central measures, this complication should not be preventable by prenatal care and thus should not be affected by the Medicaid eligibility changes. If reporting bias is present, however, we would expect Medicaid to have a positive, if anything, effect on the incidence of the 'straw man' complication. We could then use this estimated effect to make inferences about 
the extent of reporting error in the predicted effects of Medicaid on our other - preventable complications.

Based on our reading of the medical literature, diabetes best fulfills the requirements of a 'straw man' (Buchanan and Xiang 2005, Ecker 2004, Farrell 2003, Gabbe and Graves 2003, Simmons 1996). ${ }^{9}$ Its high prevalence also makes this disease a suitable candidate. ${ }^{10}$ However, the measure of diabetes available in our data is not ideal because it includes juvenile onset and adult onset diabetes in addition to the specific-to-pregnancy gestational diabetes. As such, it may be correlated with the rise in diabetes of the total population (not just pregnant women) and obesity during this time period, which may in turn be spuriously correlated with the intensity of the Medicaid expansions (if, for example, certain parts of the country experienced the largest Medicaid expansions and increases in obesity). We therefore subject this measure to several additional empirical checks. These checks confirm that: 1) our pregnancy diabetes measure is not significantly related to the overall level of diabetes in the state, 2) the overall level of diabetes is not significantly correlated with the Medicaid expansions, and 3) controlling for the overall level of diabetes in our estimating equations has no substantive impact on the results. ${ }^{11}$ Thus, while an admittedly imperfect measure, we believe that diabetes as a 'straw man' provides meaningful insight into the possible confounding effects of reporting bias on the estimated impact of the Medicaid expansions.

\section{Data Description}

Our main data come from the Natality Detail Files for the years 1989 to 1996 (U.S. Dept. of Health and Human Services, 1990-1997). These data (for the period 1990 to 1996) are used by Currie and Grogger (2002) who estimate the impacts of the Medicaid eligibility increases on 
prenatal care utilization and infant health. Since our approach here is close to that followed by Currie and Grogger (with the important exception that we focus on maternal health instead of infant health), the use of the same dataset has the advantage of making comparisons between the two studies possible. We limit our study to years prior to 1996 in order to avoid structural changes associated with the introduction of the welfare reform. ${ }^{12}$

Since 1985, the Natality Detail Files have included information on all U.S. births and so have contained more than 3 million observations annually. The large sample size is especially useful given our goal which is to study the determinants of relatively infrequent outcomes particular complications of pregnancy and delivery. Furthermore, since we estimate all of our models separately for the treatment and control groups and also want to stratify our sample by race, a large number of observations is a necessity.

The Natality Detail Files include information on maternal and infant characteristics (such as mother's age, marital status, race, Hispanic origin, education, and state of residence; and infant's sex and birth weight) as well as the characteristics of pregnancy (such as gestation and birth order) typically employed in infant health studies. In addition, since 1989, variables describing maternal morbidity during pregnancy and delivery have also been present. For example, and importantly for our purposes in this paper, the files contain information on the incidences of placental abruption, pregnancy-associated hypertension, anemia, and diabetes in pregnant women. ${ }^{13}$ This information is obtained directly from the mother's medical records. The biggest disadvantage of using the Natality Detail Files is that the dataset does not include any information on individual-level income or insurance status. Therefore, as discussed above, we rely on educational achievement as a proxy for socioeconomic status. While certainly imprecise, we believe this measure allows us to identify low SES and high SES women as 
reliably as possible. Moreover, stratification of the sample based on education seems appropriate in that educational achievement is unlikely to be affected by the Medicaid policy changes. Note also that the absence of individual-level income data does not cause a problem in constructing our Medicaid eligibility variable. To capture the exogenous effect of the Medicaid policy on pregnant women, we follow Cutler and Gruber (1996), Currie and Grogger (2002) and others and use a state-wide eligibility measure (to be described later) rather than the eligibility status of each particular individual.

In this study, we limit our sample to non-Hispanic black and white women. Since previous studies of the effects of Medicaid on prenatal care use and pregnancy outcomes document large racial differences (Dubay et al. 2001 and Currie and Grogger 2002), we stratify all of our models by race. This strategy is also supported by the fact that the "treatment probabilities' calculated from the CPS vary greatly between blacks and whites within each education/marital status group. We only look at women 19 to 50 years of age who had a singleton birth in the period from 1989 to 1996. As Joyce et al. (2003) note, the variability of educational achievement and marital status among teenage mothers is not sufficient to reliably assign these women into the treatment and control groups. Furthermore, in the case of teenage pregnancies, it is not clear whether the mother herself is the ultimate decision maker. In the baseline models, we include women with no or 'unknown' prenatal care utilization. As a robustness check, however, we also exclude these women from the analysis, and the qualitative results do not change. Foreign residents are excluded. Further, women from Louisiana and Nebraska in the year 1989, Oklahoma in years 1989-1990, and New York in years 1989-1991 are excluded due to missing information on maternal health. Mothers from Washington State in years 1989-1991 are excluded due to missing information on marital status and those from New 
Hampshire in years 1989-1992 due to missing information on ethnicity. Finally, it is important to note again that we only focus on selected treatment and control groups in the current study. These data cuts leave us with 10,855,048 observations in our final sample.

\section{Models Estimated}

To investigate the impacts of the Medicaid eligibility increases of the 1990's on prenatal care utilization and maternal health, we estimate several reduced-form models within a difference-in-differences (DID) framework. We believe our different cohorts are likely differentially affected by several other variables in our model besides the Medicaid policy variable. We therefore want to employ a more flexible model than a simple DID model that relies on a single interaction term between the policy variable and the 'treatment' indicator; in particular, we want to allow all of the coefficients to differ between the cohorts. If our outcome measures were continuous variables that could be appropriately estimated with OLS, then this could be accomplished simply (and equivalently) by estimating the equations separately for each cohort and then comparing the results between each treatment cohort and the control group.

In our case, however, the outcomes are all dichotomous and relatively infrequent, which suggests an alternative method of estimation such as logit or probit. As recently pointed out by Ai and Norton (2003) and Norton (2004), interpreting even simple interaction effects in nonlinear models is not straightforward. Rather, the interaction effect is not of the same magnitude or even necessarily the same sign as the coefficient on the interaction term and its statistical significance is not determined by the test statistic on the interaction coefficient. The true interaction effect is conditional upon the independent variables and may have different signs depending on the values of the covariates. Ai and Norton (2003) and Norton (2004) derive 
general formulas for calculating these interaction effects and their standard errors, and they devise a command within Stata (inteff) to accomplish this. However, the command requires that: 1) only two variables are interacted, which rules out the possibility of letting any other coefficient also vary by cohort, and 2) there are no nonlinear terms such as age squared, which are important to include in any birth outcomes equation. ${ }^{14}$ In addition, the authors themselves (2004, p.32) suggest that using linear probability models (OLS) may be preferable in the presence of fixed effects, which our models also include.

Given these considerations, we estimate our primary models on each cohort separately with OLS. This way, we allow all of the coefficients to differ and can include the important age quadratic plus state and time fixed effects. To examine the appropriateness of OLS, we also estimate the equations for each cohort separately using logit and then calculate and compare (but do not attempt to test) the average estimated marginal effects of the policy variable across cohorts. To retain comparability across cohorts, we evaluate these marginal effects at the same (total sample average) values of the covariates. Finding similarities between these marginal effects and those estimated with OLS provides reassurance that the results are reasonably robust to our estimation strategy.

The models we estimate consider the impacts of Medicaid and other control variables on both prenatal care utilization and maternal health outcomes. Specifically, we regress different measures of prenatal care use and maternal health $(\mathrm{Y})$ on a measure of Medicaid eligibility (ELIG), welfare caseload (CASELOAD), unemployment rate (UNEMPL), a full set of state and year dummies ( $u$ and v, respectively), and individual characteristics (X). All of our models have the following general form:

$$
\mathrm{Y}_{\text {ist }}=\alpha+\beta^{*} \mathrm{ELIG}_{\mathrm{st}}+\gamma^{*} \mathrm{CASELOAD}_{\mathrm{st}}+\delta^{*} \mathrm{UNEMPL}_{\mathrm{st}}+\mathrm{u}_{\mathrm{s}}+\mathrm{v}_{\mathrm{t}}+\theta^{*} \mathrm{X}_{\mathrm{ist}}+\varepsilon_{\mathrm{ist}},
$$


where i represents individuals, $\mathrm{s}$ states, and $\mathrm{t}$ time periods.

While the ultimate outcome of interest is maternal health, we find it useful to focus on prenatal care utilization (an input into health production in the household production framework) first. This is done in order to explore the most likely channel through which Medicaid eligibility can benefit pregnant women. We focus on two measures of prenatal care (based on Currie and Grogger 2002): 'timely prenatal care' as determined by whether the women received prenatal care in the first trimester of her pregnancy and 'adequate prenatal care' as defined by 'adequate' or 'intermediate' care on the APNCU (Adequacy of Prenatal Care Utilization) scale.

After estimating the prenatal care equations, we turn our attention to models of maternal health outcomes. As mentioned above, we focus on four measures of maternal health: the incidence of placental abruption as a complication of delivery, the incidences of pregnancyrelated hypertension and anemia as complications of pregnancy, and the incidence of at least one of the three complications listed (a 'summary variable'). In addition, we explore the impacts of the Medicaid expansions on a 'straw man' maternal complication: diabetes.

Our measure of eligibility is the state-level time-specific Medicaid eligibility cutoff (as a percent of the federal poverty line) below which pregnant women qualified for Medicaid (Hill 1992, National Governors' Association 2003). This measure is used by Currie and Grogger (2002), and, like them, we merge it to the vital statistics by half-years. This is done to account for the fact that the eligibility rules often change twice in a year. Several previous studies (e.g., Currie and Gruber 1996a, Cutler and Gruber 1996) use an alternative state-level measure of Medicaid policy: an index constructed by placing a nationally representative sample into each state and calculating its eligibility. This alternative measure is especially useful when the focus is on a variety of individual types such as infants, children and pregnant women who each may face 
different eligibility criteria. The simulated index then summarizes these differing criteria. In our case, however, we only focus on one group - pregnant women - and so we can simply use the eligibility criteria for that group. In addition to remaining comparable to Currie and Grogger (2002), our approach has the advantage of yielding the estimated effect of the policy parameter modified by the expansions and in general the easiest for policymakers to adjust.

Despite the fact that we limit our study to a period prior to the major welfare reform, the declines in welfare caseloads throughout the 1990's might have affected prenatal care utilization by pregnant women by making the access to Medicaid more difficult for them (Currie and Grogger 2002). While the link between Medicaid and welfare has formally been eliminated, an 'administrative link' between Medicaid and AFDC has persisted making the application process for Medicaid more burdensome for women not enrolled in welfare. Therefore, we must control for changes in the welfare program prior to 1996.

In our main model, we include the same welfare measure as Currie and Grogger (2002) a caseload variable that is constructed as the percentage of each state's population enrolled in the welfare program in each year (Administration for Children and Families 2003a, 2003b; U.S. Census Bureau 2003a, 2003b). While the variable clearly does not capture all of the institutional changes to the welfare program in the 1990's, it is used here as a simple proxy for the program's overall generosity. We also estimate an alternative version of the model that instead includes two key welfare policy variables: the maximum AFDC benefit for a family of three and a dummy variable for whether the state had a welfare waiver. ${ }^{15}$ However, past studies of welfare participation (e.g., Ziliak et al. 2000) typically find that the majority of variation in caseloads is explained by the above parameters and a measure of the labor market (such as the unemployment rate), which we also include. We take comfort in this finding and emphasize the model that 
includes caseloads because we believe it is a more complete summary measure of the complex welfare reforms. We are reassured by the similarity of our alternative results (and the fact that, if anything, the caseload results are a little more conservative). ${ }^{16}$

Like Currie and Grogger (2002), we include the unemployment rate (Bureau of Labor Statistics 2005) in our analyses to proxy for the general economic conditions facing women in the different state/year cells. In addition, full sets of state and year dummies are employed in order to account for state-specific, time-invariant effects and general time trends, respectively. As in Currie and Grogger (2002) and Joyce et al. (2003), we lag our policy variables (Medicaid eligibility threshold, welfare variables, and unemployment rate) by six months to allow them to impact pregnant women at a crucial stage of their pregnancies.

As for individual characteristics $X$, we use education and marital status dummies to define our treatment and control groups. We also stratify our sample by race (focusing on nonHispanic black and white mothers only). In addition, mother's age, age squared, parity, and infant gender are included in all of our models.

For reasons of computational convenience and to ensure that the observed differences in the significance of the Medicaid eligibility coefficients are not driven by vast differences in sample sizes among our treatment and control cohorts, we use a 1/3 random sub-sample of the largest highly educated/white population. We check the robustness of our findings to resampling. All standard errors are adjusted for clustering by state and year. ${ }^{17}$

\section{Descriptive Statistics}

Table 2 shows the descriptive statistics for the four treatment and one control groups of mothers, stratified by race. As can be seen, black women are substantially more likely to suffer 
from anemia than white women. Note also that this racial difference exists at all education levels, and the gap seems to be proportionally the largest among highly educated women. The incidences of placental abruption and hypertension, on the other hand, are similar across the races. ${ }^{18}$ Interestingly, among blacks, hypertension occurs much more frequently among highly educated mothers than among women from the less educated cohorts. This may perhaps be attributable to the significantly higher mean age in the highly educated sample. According to the Centers for Disease Control and Prevention, the incidence of pregnancy-associated hypertension is elevated at the extreme tails of the maternal age distribution (CDC 2003). Anemia and placental abruption are more prevalent in the less educated groups. Due to the offsetting effects of education on hypertension versus placental abruption and anemia, the incidence of 'any complication' appears fairly stable across the education cohorts. The incidence of diabetes is higher among married than among single women and, among single women, it increases with education. This pattern likely reflects the variation in maternal age.

The other patterns in Table 2 corroborate findings of previous studies. Namely, black women (in all cohorts) tend to start prenatal care later and are also less likely than white women to receive adequate care. Highly educated women have higher utilization of prenatal care than less educated mothers. Married low-educated women receive earlier and more adequate care than single low-educated women. Highly educated mothers are substantially older than less educated mothers and have fewer children on average. Black women are disproportionately represented in the 'unmarried' cohorts and, irrespective of marital status, have higher parity than white women. As expected, there are no big differences across the racial and education groups with respect to the state-level variables. On average, all cohorts face similar Medicaid eligibility thresholds, welfare caseload levels, and unemployment rates. 
Table 3 shows the trends in prenatal care utilization (represented by receipt of prenatal care in the first trimester) and maternal health in the period under study. As is apparent, in years 1989-1996, the utilization of prenatal care increased substantially. The percentage of women receiving early prenatal care rose for all education categories and the change was especially remarkable for the less educated cohorts. For example, for black single low-educated ('less than high school') women - the most 'disadvantaged' group - the percentage of those receiving prenatal care in the first trimester of their pregnancy increased from about 48\% in the year 1989 to approximately $60 \%$ in the year 1996.

As also evident from Table 3 , the incidence of anemia initially slightly decreased (reaching minimum in years 1990-1992) and then kept increasing (for most cohorts) during the mid-1990's. This pattern was even stronger for hypertension. The incidence of placental abruption, on the other hand, did not change or declined modestly. As a CDC report notes, anemia and hypertension were (in addition to diabetes) among the three most common complications of pregnancy in the 1990-1999 period and "their rates have risen steadily" (27\% increase in anemia and 40\% increase in hypertension; CDC 2001, p.11). Unfortunately, a simple descriptive analysis does not enable us to study the underlying causes of these observed trends. Most likely, several factors affected the incidence of maternal complications simultaneously. For example, average maternal age first modestly decreased and then increased in the mid-1990's. If maternal age is an important determinant of women's health, this could explain some of the observed patterns. Similarly, an initial acceleration and a later slowdown of the Medicaid eligibility expansions would be consistent with the observed trends. To account for all of these concomitant changes, a multivariate approach is needed. 
As we discussed in section 3 , another problem with the reported numbers is that they do not enable us to distinguish between a 'true' increase in maternal complications and a better monitoring of already existing morbidities. As the CDC report acknowledges: "Some of the apparent increases since 1990 may be an artifact of improved reporting." (CDC 2001, p.11) As long as the improvements in reporting have been universal (independent of the Medicaid expansions), their effects should be captured by the year dummies and should not bias our policy coefficients. It is highly probable, however, that the Medicaid expansions did contribute to better reporting. If women targeted by the Medicaid program had traditionally been those most likely to go without prenatal care and if Medicaid succeeded in providing these women with such care (of which pregnancy monitoring is a key component), we could observe a positive correlation between the Medicaid expansions and the reported maternal complications.

We take some comfort in the fact that - based on the descriptive statistics - the 'bad' trends seem to have been similar across the education cohorts. Moreover, even if our estimates of the 'true' beneficial impacts of the expansions suffer from this reporting bias, the direction of the bias will be downward, making our results conservative. And, finally, our analysis of diabetes provides a 'straw man' against which to compare the central results. Specifically, as argued above, diabetes does not seem to be preventable by prenatal care. Thus, any effect of the Medicaid expansions on the incidence of diabetes would only reflect improvements in reporting. The steady increase in the incidence of diabetes during1989-1996 (Table 3) is at least consistent with this hypothesis.

\section{Empirical Results}

\section{Medicaid Eligibility}


Table 4 reports the effects of the Medicaid policy variable on the utilization of prenatal care and maternal health measures (both preventable and 'straw man') for our primary model that includes welfare caseloads and is estimated with OLS. Note that each cell in Table 4 is from a different regression and that the first column repeats the estimated 'enrollment treatment probability' for each group from Table 1.

The results from the logit analysis and the alternative OLS model that uses welfare policy variables instead of caseloads are similar and available upon request. Comparing across estimation techniques, the marginal effects from the logit and the OLS coefficients are similar in both magnitude and statistical significance. This lends support to our estimation strategy and allows us to focus our discussion on the OLS results which are easier to interpret. Likewise, comparing across welfare measures reveals that using policy variables instead of caseloads has little impact on the results, with the important exception that prenatal care is more strongly affected for our most heavily 'treated' group - married, very low educated mothers -- when the policy variables are used. The general finding from Table 4 is that the Medicaid expansions of the 1990's benefited less educated mothers, especially whites. First, as apparent, increases in Medicaid eligibility significantly increase the probability of receiving prenatal care in the first trimester and of receiving adequate or intermediate prenatal care among less educated single women (TR \#2-4, both black and white; second and third columns of Table 4). If welfare policy variables are used instead of caseloads, the same is true for married, very low educated mothers of both races (TR\#1). On the other hand, as hypothesized, the eligibility coefficients are at best marginally significant (blacks) or have the opposite sign (whites) among highly educated mothers. This finding corroborates the results in Currie and Grogger (2002) where women with low socioeconomic status benefited from the Medicaid expansions but women with high 
socioeconomic status did not. When testing for the significance of the differences, we strongly reject the null hypothesis that unmarried 'treatment' (TR \#2-4) and 'control' women are affected equally. ${ }^{19}$ We also see that the magnitude of the effect diminishes steadily as education increases. Surprisingly, however, the beneficial effect of Medicaid in promoting prenatal care use did not reach statistical significance among low-educated married women of either race and its estimated magnitude is also smaller.

The fourth column in Table 4 presents our results for placental abruption. As can be seen, there is no strong evidence of a beneficial effect of the Medicaid eligibility expansions on the incidence of this complication. This is not too surprising given the rarity of the event: in the 1989-1996 period, no more than 1\% of women suffered from placental abruption in any of our sub-samples (Table 2).

The results for the other three measures of preventable complications are more supportive of an effect of Medicaid, as the estimated coefficients are universally of the correct sign and in general are the largest in magnitude for the most disadvantaged women. In other words, the effectiveness of Medicaid tends to die off as one moves from the most heavily treated groups (TR \#1 and 2), to those less intensely treated (TR \#3 and 4) and those assumed not to be treated at all (Control). This is an important finding precisely because we have included a more exhaustive list of potential treatment groups, of which some (the intermediate ones) are less likely to have been treated.

Column five reports suggestive results for anemia: while not significant at conventional levels, all of the Medicaid eligibility coefficients are negative among women in the treatment groups and the sizes of the effects are sometimes substantial. ${ }^{20}$ The causality of the relationship between anemia and Medicaid is further supported by the fact that neither black nor white 
'control' mothers seem to have been affected by the policy changes (the coefficients are very small in magnitude and positive in these cohorts). These are potentially important findings given that anemia has been a relatively common complication of pregnancy (over 3\% of less educated blacks and close to $2 \%$ of less educated whites suffered from anemia in the 1989-1996 period; Table 2).

The results for hypertension in the sixth column are even stronger, especially for white mothers. Again, the eligibility coefficients always have the correct sign among women in the treatment groups and tend to be the largest for those most likely to have been treated. Furthermore, the beneficial effects of Medicaid are significant among white women with 'less than high school' education (both married and single - TR \#1 and 2) and, in the logit model, marginally significant among single black and white mothers with 'high school completed' (TR \#3). The results for the summary measure (experiencing 'any complication') are reported in the seventh column. The Medicaid expansions appear to have reduced the incidence of any of the three maternal complications studied among women most likely to be 'treated' - married, very low-educated mothers (TR \#1). For whites, single low-educated mothers are also affected. The effects are also sizeable ( 0.2 to 0.9 percentage point reduction in risk). This is an important result given that $5-7 \%$ of women in our sample suffered from at least one of the preventable morbidities in the 1989-1996 period (Table 2).

The final column of Table 4 reports the results of our 'straw man' measure, diabetes. As hypothesized, Medicaid eligibility has no beneficial effect. In fact, the coefficients on diabetes are positive and statistically significant among white women with at least high school education. This result is consistent with the concept of improved reporting discussed earlier. In particular, since diabetes is not believed to be preventable by prenatal care and since the Medicaid 
expansions likely improved monitoring of maternal morbidities, we would expect the effect of Medicaid on the observed incidence of diabetes to be positive, if anything. ${ }^{21}$

To isolate the causality and get more insight into the reporting bias present in our maternal health estimates, we subject these estimates to several tests, summarized in Table 5. The first one is the usual test of no effect $\left(\boldsymbol{B}_{\text {prev }}^{\mathbf{t}}=\mathbf{0}\right)$ and repeats the t-statistics reported in Table 4 for each preventable complication for the treatment groups. The second tests whether the differential effect of Medicaid on the treatment group as opposed to the control group is zero $\left(\boldsymbol{B}_{\text {prev }}^{\mathbf{t}}-\boldsymbol{\aleph}_{\text {prev }}^{\mathbf{c}}=0\right)$. This corresponds to the typical 'difference-in-difference' test comparing treatment to control groups and is also reported by the 'shaded' cells in Table 4. The third exercise examines the extent of possible reporting bias by testing the difference in the Medicaid coefficients for preventable complications from those for our 'straw man,' diabetes $\left(\mathbf{B}_{\text {prev }}^{\mathbf{t}}-\mathbf{B}_{\text {diab }}^{\mathbf{t}}=\right.$ 0 ). If all complications share the same reporting bias, then subtracting the diabetes coefficient is essentially purging the preventable complications' estimates of this bias. Of course, this is a very strong assumption and so we view these calculations and tests as illustrative only. Also, we caution that our exercise compares percentage point changes in the outcomes of interest which limits its applicability in situations where the incidence of maternal complications vastly differs. For example, the incidence of placental abruption is generally much lower than the incidence of diabetes. (It also seems far less likely to be misreported.) Anemia and hypertension, on the other hand, are as common as diabetes and a change in their incidence can thus more reliably be compared. Finally, the fourth test combines the second and third by purging the difference-indifference estimates of possible reporting bias $\left(\left(\boldsymbol{B}_{\text {prev }}^{\mathbf{t}}-\boldsymbol{B}_{\text {diab }}^{\mathbf{t}}\right)-\left(\mathbf{B}_{\text {prev }}^{\mathbf{c}}-\mathbf{B}_{\text {diab }}^{\mathbf{c}}\right)=0\right)$.

For all four exercises, we report both the t-statistics and the $95 \%$ confidence intervals on the predicted effects. We report the confidence intervals in order to gain further insight into the magnitude of the possible effects and also as a way of exploring whether our marginally significant estimates are due to 
low power or truly small effects (as recommended by Hoenig and Heisey, 2001). To provide context for these estimated ranges of effects, we report the observed incidence of the complication for each sample in the first column of Table 5. One can view these observed incidences as a naïve probability and the range of estimates as the potential changes in that probability as a result of a 100 percentage point increase in the Medicaid eligibility threshold. The average Medicaid threshold increased from $94 \%$ to $170 \%$ of the federal poverty level during 1989-1996 for an actual average increase of 76 percentage points. Thus, the predicted changes in probability coincide fairly closely with the average 'policy treatment.'

For the most part, these exercises confirm the results in Table 4. Placental abruption appears unaffected by Medicaid for both black and white mothers. Not only are none of the calculated differences significantly different from zero, the predicted range of effects is also tightly clustered around and centered at zero.

For the rest of the complications, the results are again suggestive but not definitive; they are also strongest for whites and for the summary complication measure. As expected, adjusting for measurement error (the third hypothesis) typically increases both the statistical significance and potential magnitude of the effects. Likewise, comparing treatment vs. control (the second hypothesis) tends to reduce the significance and has a more mixed effect on the potential magnitudes. The combined adjustment (the fourth hypothesis) never produces a significant result and may simply be asking too much of the data.

The confidence intervals reveal that the effects are of a potentially meaningful magnitude. For example, in one of the strongest cases (white mothers TR\#1 and 2, any complication) the upper limit is approximately .01, which results in an approximate 20 percent reduction in the overall incidence (.01 out of .05). Even in the statistically insignificant cases, the upper limit represents a similarly sized (or greater) reduction. This is especially true for black 
mothers, suggesting that the disappointing effects for blacks may be due more to low power (high variance) rather than small effects (small coefficients).

\section{Sensitivity Checks}

Before further exploring our main results, we test their robustness by conducting several sensitivity checks. ${ }^{22}$ First, we re-estimate our models excluding 1989 from the analysis. 1989 is the first year when maternal complications were recorded in the Natality Detail Files and we want to verify that the adoption of new birth certificates did not somehow contaminate our findings. In addition, information on maternal health outcomes is missing for three states Louisiana, Nebraska, and Oklahoma - in the year 1989. Limiting the period studied to 19901996 mostly leaves our conclusions qualitatively unchanged, but in the case of married black mothers (TR \#1) and unmarried lowest educated white mothers (TR \#2) the results are substantially stronger.

Second, we redefine prenatal care adequacy as receiving 'adequate' (as opposed to 'adequate' or 'intermediate') prenatal care. The results remain qualitatively the same. This is also true if we exclude women with 'no' or 'unknown' prenatal care utilization from the analysis. Likewise, drawing different random samples ( $1 / 3$ of all births) from the control white population has little influence on our estimates.

Finally, we explore the impact of pooling our four treatment groups into one. This way, we avoid stratifying by marital status which, as noted by Yelowitz (1998) and others, could be affected by Medicaid. Estimating our primary model for the pooled 'treatment' group leads to very similar results. Prenatal care increases for both black and white treatment groups but maternal health is only improved for the white treatment group, with hypertension and the 
summary measure being significantly affected. Our sensitivity analyses, including the earlier ones of an alternative estimation method and measure of welfare, therefore reveal our main results to be robust and conservative, if anything, especially with regards to married women (TR \#1)

The Possible Roles of Race, WIC and Parity on Medicaid's Effectiveness

The apparent racial differences in the effects of Medicaid on prenatal care use and maternal health merit further discussion. Our findings suggest that both black and white mothers obtained more adequate prenatal care as a result of the Medicaid expansions. Indeed, the same treatment groups for both races (i.e., single mothers) experienced improvements that are significantly different from the effects on the corresponding control groups (Table 4). Among treatment whites, the increases in access translated into improved maternal outcomes even among those who may not have experienced improvements in our measures of prenatal care (i.e., married women; recall that alternative specifications sometimes produce significant improvements in this group as well). Among blacks, on the other hand, few improvements in maternal health are observed and none are statistically different from the effects on the control group. There also appears to be little evidence of reporting bias for this group.

A further puzzle is that the cohorts that appear most affected in terms of maternal health less educated married mothers - did not apparently experience an increase in our measures of prenatal care. However, as suggested by our alternative model that includes welfare policy variables instead of caseloads, this result is not very robust. In particular, it seems possible that these women did in fact experience some improvements in prenatal care. Another explanation of the puzzle is that the effect of Medicaid for these mothers is not operating through improved 
prenatal care but rather through some other channel, such as WIC. In section 2, we note that: 1) the Medicaid expansions may have increased WIC participation and 2) calcium supplements have been shown to prevent hypertension (which in turn may prevent placental abruption) and iron supplements can prevent anemia. Since WIC requires that provided foods contain calcium and iron (as well as protein and vitamins A and C; Bitler and Currie 2005, pp.75-6), the program may reinforce the effects of Medicaid on maternal health.

Could the role of WIC also explain the racial disparities we observe in the unmarried treatment groups? Brien and Swann (2001) provide evidence that black women's prenatal participation in WIC is more influenced by state WIC program rules and is also more likely to improve the birth outcome. Their results therefore suggest that the effects of the Medicaid expansions (to the extent they are capturing increased WIC participation) should be stronger for black mothers whereas we find the opposite. Thus, while WIC may explain why married mothers experienced improvements in health without significant improvements in prenatal care, it does not explain the racial disparities we find more generally.

Perhaps the racial differences among unmarried mothers could be due to the lower sample sizes/lower power among blacks (especially for TR \#1 and the control group, as evident in Table 2) or the smaller estimated probability of 'treatment' we find in our CPS analysis (Table 1). However, these two explanations seem inconsistent with the highly statistically significant (and substantial) improvements in the utilization of prenatal care experienced across the races, although the much lower incidence of maternal complications could perhaps magnify the impact of smaller sample sizes. ${ }^{23}$

Another possible explanation for this phenomenon is that black women receive a lower quality of prenatal care than whites. The role of prenatal care quality is mentioned in Currie and 
Grogger (2002), who find a similar pattern of strong racial differences in the effects of Medicaid on prenatal care use and infant health. Unfortunately, the quality of prenatal care cannot be investigated using data from the vital statistics. Suggestive evidence, however, can be found in other studies. For example, Kogan et al. (1994) and Conway and Kutinova (2006) find that pregnant blacks are less likely than pregnant whites to receive advice on cessation of alcohol consumption and smoking cessation even when the timing of prenatal care initiation is controlled for. In a recent paper, Chandra and Skinner (2003) argue that blacks tend to seek care in areas where quality levels for all patients (black and white) are lower.

Yet another explanation for the observed racial disparities can be found in Geronimus and Bound (1990). The authors' main argument is that the health of black women deteriorates with age more rapidly than the health of white women and that this can be attributed to a cumulative effect of poor medical care among blacks. If so, black women may have more preexisting morbidities when they reach their childbearing age which can make it more difficult for prenatal care providers to intervene. Using hospital discharge data from South Carolina, Laditka et al. (2006) find disparities in the incidence of potentially preventable maternal complications between black and white mothers enrolled in Medicaid. Interestingly, these racial disparities are eliminated once socio-economic characteristics and comorbidities are controlled for.

Finally, there is the possible role of parity and fertility behavior more generally. Either the effectiveness of prenatal care or the decision to seek prenatal care could differ by parity and therefore by race. Primiparity (one's first pregnancy) has been consistently found to be associated with increased hypertension and other delivery complications, even after controlling for age (Villar et al. 2006, Royer 2004, Handa et al. 2001, Kyrklund-Blomberg et al. 2001, Herbert et al. 1999). At the same time, women may gain more information from prenatal care 
received during their first pregnancy, affecting both the effectiveness of prenatal care and their decisions to seek such care. Our own (unreported) results suggest that increased parity leads to less prenatal care. And, all of these avenues have the potential to differ by race. In our samples, for example, the percentage of first births (primiparous) is substantially lower for black women, especially for the least educated cohorts (Table 2).

We therefore re-estimate our main model for primiparous women only. These results are reported in Table 6 and provide some evidence that parity could be playing a role. For white mothers, the results are qualitatively similar to those for the full sample but the magnitudes are frequently bigger. For black mothers, despite the dramatic reductions in sample sizes, the effects appear slightly stronger for unmarried women. For black married women (TR \#1), the enormous reduction (almost 90\%) in what was already our smallest sample eliminates the earlier modestly encouraging results. It is therefore possible that parity may play a role in the effectiveness of Medicaid on maternal health and help explain the racial differences we observe.

Fertility behavior more generally could also be playing a role. As explored in Bitler and Zavodny (2004), the Medicaid expansions may affect the fertility decisions of potentially eligible women and thus have an indirect effect on maternal health outcomes (if, for example, less healthy women decide to give birth). Their findings suggest that Medicaid may affect fertility differently depending on socioeconomic status. In sum, finding racial differences in health outcomes, birth outcomes in particular, is not a new result. There are many plausible explanations and pathways, including WIC, quality of care and fertility behavior, that merit future investigation.

\section{Other Results}


What factors besides Medicaid affect maternal health? In Table 7, we report the full set of results (except for state and year dummy coefficients) for the incidence of 'any complication' estimated with OLS. (The full sets of results from the other models are available upon request.) Among white treatment women, welfare surprisingly seems to modestly increase the incidence of pregnancy complications. Among blacks, it has the expected effect of modestly decreasing complications. The result for whites probably reflects the positive association between poverty and health care need, although the racial disparity is again difficult to explain. The effects of unemployment are insignificant.

As expected, the incidence of 'any complication' first decreases (until the mid to late 20s) and then increases with maternal age. ${ }^{24}$ Controlling for age, parity generally decreases the probability of complications, which is consistent with past studies cited above. And, finally, having a male infant is associated with more complications among whites but with fewer complications among blacks. This finding may be attributable to a differential effect of infant gender on the incidence of specific morbidities. In particular, our unreported results suggest that male infants are associated with a higher incidence of hypertension (at least among whites) and with a lower incidence of anemia (among both blacks and whites).

\section{Concluding Remarks}

Overall, our results suggest that there may have been an additional beneficiary of the Medicaid expansions of the 1990's - the mother. Specifically, the eligibility changes led to a higher utilization of prenatal care among those women (i.e., economically disadvantaged) most likely to have benefited from the expansions. The extent to which these improvements in prenatal care translated into improvements in maternal health is less clear. For white mothers, the 
evidence is supportive, although not definitive, that maternal health outcomes improved as well. The evidence is strongest for hypertension and our 'any complication' summary measure and for the groups most likely to have been treated; it is further strengthened, if anything, by attempts to purge the estimates of reporting bias. For black mothers, the estimated magnitudes are similar but are rarely statistically significant. Despite our large sample sizes, we suspect that our results may suffer from low power. This is especially true for our smaller black samples, in light of the very low incidence of these complications and the fact that our key variable - Medicaid eligibility- only varies across states and time.

Even so, our estimates suggest potentially meaningful decreases in maternal complications due to the Medicaid expansions. To get a better idea about the magnitude of the estimated health effects, consider an example of California in the year 1989. In the early 1990's, California experienced an increase in the Medicaid eligibility threshold from 109 to 185 percent of the federal poverty line (this was one of the largest percentage point increases nationally). Based on our primary (statistically significant) results, such an increase would be associated with a decline in the incidence of hypertension of:

$12.3 \%$ among married whites with 'less than high school' education, and $10.0 \%$ among single whites with 'less than high school' education. Similarly, the Californian expansion would cause a decline in the incidence of 'any complication' of:

$10.4 \%$ among married blacks with 'less than high school' education, $7.5 \%$ among married whites with 'less than high school' education, and 7.2\% among single whites with 'less than high school' education. 
Given the costs of pregnancy complications to the mother and society, these are not negligible improvements.

The results of our research also reveal that maternal health improved among some disadvantaged mothers who may not have experienced a significant change in the timing and/or adequacy of prenatal care. Conversely, other women (such as single blacks) experienced an increase in prenatal care access but failed to experience improved maternal health. These findings beg the question of what other channels exist through which Medicaid eligibility actually affects maternal health. Nonetheless, according to our findings, the potential of public policies to improve the health status of disadvantaged pregnant women may be large. 


\section{References}

Administration for Children and Families. 2003a.

Accessed 10/02/2003. Available at http://www.acf.dhhs.gov/programs/opre/afdc/afdc.htm. Administration for Children and Families. 2003b.

Accessed 10/01/2003. Available at http://www.acf.dhhs.gov/news/stats/caseload.htm.

Agency for Healthcare Research and Quality (AHRQ). 1996. Hospital Inpatient Statistics, 1996.

Accessed 03/27/2004. Available at http://www.ahcpr.gov/data/hcup/his96/table1d.htm.

Ai, Chunrong and Edward C. Norton. 2003. Interaction Terms in Logit and Probit Models.

Economics Letters 80:123-29.

American Academy of Pediatrics, American College of Obstetrics and Gynecology (ACOG).

Guidelines for Perinatal Care, second edition, 1988.

Bashiri, A.; E. Burstein, E. Sheiner, and M. Mazor. 2003. Anemia during Pregnancy and

Treatment with Intravenous Iron: Review of the Literature. European Journal of Obstetrics, Gynecology, and Reproductive Biology 110:2-7.

Bitler, Marianne P. and Janet Currie. 2005. Does WIC Work? The Effects of WIC on Pregnancy and Birth Outcomes. Journal of Policy Analysis and Management 24:73-91.

Bitler, Marianne P. and Madeline Zavodny. 2004. The Effects of Medicaid Eligibility Expansions on Fertility. Unpublished paper.

Brien, Michael J. and Christopher A. Swann. 2001. Prenatal WIC Participation and Infant Health: Selection and Maternal Fixed Effects. Unpublished paper.

Brown ZA. 2000. HSV-2 specific serology should be offered routinely to antenatal patients. Reviews in Medical Virology 10:141-4. 
Brown ZA; Gardella C, Wald A, Morrow RA, and Corey, L. 2005. Genital herpes complicating pregnancy. Obstetrics and Gynecology 106:845-56.

Buchanan, Thomas A. and Anny H. Xiang. 2005. Gestational Diabetes Mellitus. The Journal of Clinical Investigation 115:485-491.

Bureau of Labor Statistics. 2005. Local Area Unemployment Statistics.

Accessed 04/24/2005. Available at http://data.bls.gov/cgi-bin/surveymost?la.

Busch, Susan H. and Noelia Duchovny. 2005. Family Coverage Expansions: Impact on Insurance Coverage and Health Care Utilization of Parents. Journal of Health Economics 24:876-890.

Centers for Disease Control and Prevention (CDC). 1989. Sexually Transmitted Diseases:

Treatment Guidelines 1989. Accessed 27/10/2006. Available at

http://www.cdc.gov/mmwr/preview/mmwrhtml/00001459.htm.

Centers for Disease Control and Prevention (CDC). 2001. National Vital Statistics Report, 49:1. Accessed 12/15/2003. Available at http://www.cdc.gov/nchs/data/nvsr/nvsr49/nvsr49_01.pdf.

Centers for Disease Control and Prevention (CDC). 2003. National Vital Statistics Report, 52:10. Accessed 02/01/2004. Available at http://www.cdc.gov/nchs/data/nvsr/nvsr52/nvsr52_10.pdf.

Centers for Disease Control and Prevention (CDC). 2006. Sexually Transmitted Diseases:

Treatment Guidelines 2006. Accessed 27/10/2006. Available at

http://www.cdc.gov/std/treatment/2006/specialpops.htm\#specialpops1.

Chandra, Amitabh and Jonathan Skinner. 2003. Geography and Racial Health Disparities. NBER Working Paper No. 9513.

Chatterji, Pinka and Sara Markowitz. 2005. Does the Length of Maternity Leave Affect Maternal Health? Southern Economic Journal 72:16-41. 
Conway, Karen S. and Andrea Kutinova. 2006. Maternal Health: Does Prenatal Care Make a Difference? Health Economics 15:461-488.

Currie, Janet and Jeffrey Grogger. 2002. Medicaid Expansions and Welfare Contractions: Offsetting Effects on Prenatal Care and Infant Health? Journal of Health Economics 21:313-35. Currie, Janet and Jonathan Gruber. 1996a. Saving Babies: The Efficacy and Cost of Recent Changes in the Medicaid Eligibility of Pregnant Women. Journal of Political Economy 104:1263-1296.

Currie, Janet and Jonathan Gruber. 1996b. Health Insurance Eligibility, Utilization of Medical Care, and Child Health. The Quarterly Journal of Economics 111:431-466.

Currie, Janet and Jonathan Gruber. 1997. The Technology of Birth: Health Insurance, Medical Interventions, and Infant Health. NBER Working Paper No. 5985.

Currie, Janet and Jonathan Gruber. 2001. Public Health Insurance and Medical Treatment: The Equalizing Impact of the Medicaid Expansions. Journal of Public Economics 82:63-89.

Cutler, David M. and Jonathan Gruber. 1996. Does Public Insurance Crowd Out Private Insurance? The Quarterly Journal of Economics 111:391-430.

Dashe JS; Nathan L, McIntire DD, and Leveno KJ. 2000. Correlation between amniotic fluid glucose concentration and amniotic fluid volume in pregnancy complicated by diabetes. American Journal of Obstetrics and Gynecology 182:901-4.

Decker, Sandra L. and Carol Rapaport. 2002. Medicare and Disparities in Women's Health. NBER Working Paper No. 8761.

Dubay, Lisa; Ted Joyce, Robert Kaestner, and Genevieve M. Kenney. 2001. Changes in Prenatal Care Timing and Low Birth Weight by Race and Socioeconomic Status: Implications for the Medicaid Expansions for Pregnant Women. Health Services Research 36:373-398. 
Ecker, Jeffrey L. 2004. Gestational Diabetes: Are Prediction and Prevention Possible? Diabetes Forecast Jan 2004:109-111.

Farrell M. 2003. Improving the Care of Women with Gestational Diabetes. The American Journal of Maternal Child Nursing 28:301-305.

Gabbe, SG and CR Graves. 2003. Management of Diabetes Mellitus Complicating Pregnancy. Obstetrics and Gynecology 102:857-868.

Geocities, 2004. National Health Statistics - National Bill. Data source: HCUPnet, Healthcare Cost and Utilization Project. Agency for Healthcare Research and Quality, Rockville, MD. Accessed 02/01/2004. Available at http://www.geocities.com/s7ss/National_Health_Bill.htm. Geronimus, Arline T. and John Bound. 1990. Black/White Differences in Women’s Reproductive-Related Health Status: Evidence from Vital Statistics. Demography 27:457-466. Haas, Jennifer S.; Steven Udvarhelyi, and Arnold M. Epstein. 1993. The Effects of Health Coverage for Uninsured Pregnant Women on Maternal Health and the Use of Cesarean Section. JAMA 270:61-64.

Handa, VL; BH Danielsen, and WM Gilbert. 2001. Obstetric anal sphincter lacerations. Obstetrics And Gynecology 98:225-30.

Hebert, PR; G Reed, SS Entman, EF Jr Mitchel, C Berg, and MR Griffin. 1999. Serious maternal morbidity after childbirth: prolonged hospital stays and readmissions. Obstetrics And Gynecology 94:942-7.

Hill, Ian T. 1992. The Medicaid Expansions for Pregnant Women and Children: A State Program Characteristics Information Base. Washington, D.C.: Health Systems Research. Hoenig, John M. and Dennis M. Heisey. 2001. The Abuse of Power: The Pervasive Fallacy of Power Calculations for Data Analysis. The American Statistician 55:19-24. 
Joyce, Ted; Robert Kaestner, and Sanders Korenman. 2003. Welfare Reform and Non-Marital Fertility in the 1990s: Evidence from Birth Records. Advances in Economic Analysis and Policy 3:1, Article 6.

Kaestner, Robert; Ted Joyce, and Andrew Racine. 2001. Medicaid Eligibility and the Incidence of Ambulatory Care Sensitive Hospitalizations for Children. Social Science and Medicine 52:305-313.

Kaestner, Robert and Neeraj Kaushal. 2004. The Effect of Welfare Reform on Health Insurance Coverage of Low-income Women and Children. Journal of Health Economics 22:959-981.

Kaestner, Robert and Elizabeth Tarlov. 2003. Changes in the Welfare Caseload and the Health of Low-educated Mothers, NBER Working Paper No. 10034.

Kogan M.D.; M. Kotelchuck, G. Alexander, and W.E. Johnson. 1994. Racial Disparities in Reported Prenatal Care Advice from Health Care Providers. American Journal of Public Health 84:82-88.

Kyrklund-Blomberg, NB; G Gennser, and S Cnattingius. 2001. Placental abruption and perinatal death. Paediatric And Perinatal Epidemiology 15:290-7.

Laditka, Sarah B.; James N. Laditka, Melanie P. Mastanduno, Michele R. Lauria, and Tina C. Foster. 2005. Potentially Avoidable Maternity Complications: An Indicator of Access to Prenatal and Primary Care during Pregnancy. Women and Health 41:1-26.

Laditka, Sarah B.; James N. Laditka, and Janice C. Probst. 2006. Racial and Ethnic Disparities in Potentially Avoidable Delivery Complications Among Pregnant Medicaid Beneficiaries in South Carolina. Maternal and Child Health Journal, In press.

Lewbel, Arthur. 2003. Estimation of Average Treatment Effects with Misclassification, Boston College Working Paper in Economics No. 556, Boston College, Chestnut Hill, Massachusetts. 
Lewis, Kimball and Marilyn Ellwood. 1999. Medicaid Policies and Eligibility for WIC, submitted to U.S. Department of Agriculture, Food and Nutrition Service.

Lopez-Jarmillo, Patricio; Ronald G. Garcia, and Marcos Lopez. 2005. Preventing PregnancyInduced Hypertension: Are There Regional Differences for This Global Problem? Journal of Hypertension 23:1121-1129.

Makrides, M.; C.A. Crowther, R.A. Gibson, R.S. Gibson, and C.M. Skeaff. 2003. Efficacy and Tolerability of Low-dose Iron Supplements during Pregnancy: A Randomized Controlled Trial. American Journal of Clinical Nutrition 78:145-53.

National Governors’ Association. 2003. Maternal and Child Health (MCH) Updates, 1994-1999 Issues. Accessed 09/27/2003. Available at http://www.nga.org.

Norton, Edward C. 2004. Interaction Terms in Logit and Probit Models, AcadamyHealth, presentation. Accessed 06/21/2006. Available at http://www.unc.edu/\%7Eenorton/InteractionAcademyHealth2004.pdf.

Patel R. 2004. Educational interventions and the prevention of herpes simplex virus transmission, Herpes 11:Supp1 3:155A-160A.

Patel R and Rompalo A. 2005. Managing patients with genital herpes and their sexual partners. Infectious Disease Clinics of North America 19:427-38.

Preeclampsia Foundation, 2004. The Cost of Preeclampsia in the USA. Data source: Agency for Healthcare Research and Quality and Centers for Disease Control and Prevention. Accessed 02/01/2004. Available at http://www.preeclampsia.org/statistics.asp.

Public Health Service. 2000. Healthy People 2010: Objectives for Improving Health, U.S. Department of Health and Human Services, Public Health Service, Washington D.C. 
Rouse DJ and Stringer JS. 2000. An appraisal of screening for maternal type-specific herpes simplex virus antibodies to prevent neonatal herpes. American Journal of Obstetrics and Gynecology 183:400-6.

Royer, Heather. 2004. What All Women (and Some Men) Want to Know: Does Maternal Age Affect Infant Health?, Center for Labor Economics, University of California, Berkeley, Working Paper No. 68.

Sachs BP, DA Brown, SG Driscoll, E Schulman, D Acker, BJ Ransil, and JF Jewett. 1988. Hemorrhage, Infection, Toxicemia, and Cardiac Disease, 1954-85: Causes for their Declining Role in Maternal Mortality. American Journal of Public Health 78:671-5.

Scholl TO, ML Hediger, and DH Belsky. 1994. Prenatal Care and Maternal Health during Adolescent Pregnancy: A Review and Meta-Analysis. Journal of Adolescent Health 15:444-456. Simmons, David. 1996. Can Gestational Diabetes/Non-Insulin-Dependent Diabetes in Pregnancy be Prevented? The Australian and New Zealand Journal of Obstetrics and Gynaecology 36:117119.

U.S. Census Bureau. 2003a.

Accessed 10/02/2003. Available at http://eire.census.gov/popest/archives/1990\#state.

U.S. Census Bureau. $2003 b$.

Accessed 10/01/2003. Available at http://www.census.gov/population/estimates/state/st-99-3.txt.

U.S. Dept. of Health and Human Services, National Center for Health Statistics. 1990-1997.

Natality Detail File, 1989-1996. Hyattsville, MD: U.S. Dept. of Health and Human Services, National Center for Health Statistics [producer], 1990-1997. Ann Arbor, MI: Inter-University Consortium for Political and Social Research [distributor], 2003. 
Villar, J; G Carroli, D Wojdyla, E Abalos, D Giordano, H Ba'aqeel, U Farnot, P Bergsjø, L Bakketeig, P Lumbiganon, L Campodónico, Y Al-Mazrou, M Lindheimer, and M Kramer. 2006. Preeclampsia, gestational hypertension and intrauterine growth restriction, related or independent conditions? American Journal Of Obstetrics And Gynecology 194:921-31.

Villar, J.; M. Merialdi, A.M. Gulmezoglu, E. Abalos, G. Carroli, R. Kulier, and M. de Onis. 2003. Nutritional Interventions during Pregnancy for the Prevention or Treatment of Maternal Morbidity and Preterm Delivery: An Overview of Randomized Controlled Trials. Journal of Nutrition 133 (Suppl 2):1606S-1625S.

Yelowitz, Aaron S. 1998. Will Extending Medicaid to Two-Parent Families Encourage Marriage? The Journal of Human Resources 33:833-865.

Ziliak, James P.; David N. Figlio, Elizabeth E. Davis, and Laura S. Connolly. 2000. Accounting for the Decline in AFDC Caseloads: Welfare Reform or the Economy? Journal of Human Resources 35:570-5. 


\section{Endnotes}

${ }^{1}$ The Healthy People 2010 include an explicit objective to "reduce maternal illness and complications due to pregnancy" (Objective 16-5) which involves reduction in "prenatal illness and complications" as well as "complications during labor and delivery."

2 "Premature separation of a normally implanted placenta from the uterus." (CDC 2003)

3 “An increase of blood pressure of at least $30 \mathrm{~mm} \mathrm{Hg}$ systolic or $15 \mathrm{~mm} \mathrm{Hg}$ diastolic on two measurements taken 6 hours apart after the $20^{\text {th }}$ week of gestation.” (CDC 2003)

4 "Hemoglobin level of less than $10.0 \mathrm{~g} / \mathrm{dL}$ during pregnancy or a hematocrit of less than 30 percent during pregnancy." (CDC 2003)

${ }^{5}$ For the sake of comparability, we follow the general spirit of the infant health literature (Currie and Grogger 2002) and treat marital status as exogenous. As some have suggested, however, the decision to marry might have itself been affected by the changes in the Medicaid eligibility rules (Yelowitz 1998). We explore this issue further in the robustness checks of our main results.

${ }^{6}$ Married women could only qualify for the AFDC-UP (Unemployed Parent) program which provided transitional cash assistance to families in which both parents were living in the household and the principal earner, whether the father or the mother, was unemployed. 
${ }^{7}$ The CPS does not report whether a woman was pregnant. In addition, Medicaid eligibility at the individual level is not possible to determine, so we cannot explore the extent of increased eligibility within our sample groups.

${ }^{8}$ The results of this analysis are available upon request.

${ }^{9}$ We have considered several other complications available in the NDF for the 'straw man' exercise. Since our goal is to address the reporting issue, complications of labor and delivery which are hard to miss with a vast majority of deliveries occurring in a hospital - are not very suitable. Therefore, we have focused on pregnancy complications ('medical risk factors') instead. A problem with this approach is the rarity of most of the complications reported. For example, the following risk factors occurred in less than $0.5 \%$ of pregnancies in the year 1990 : cardiac disease, lung disease, hemoglobinopathy, eclampsia, incompetent cervix, and renal disease. With the incidence of the 'straw man' complication significantly below the incidence of the main outcomes studied, 'bias-purged' estimates become problematic. Furthermore, the most frequent adverse events reported in the data (apart from diabetes, hypertension, and anemia) 'previous infant 4000+ grams' and 'previous preterm or small-for-gestational-age infant' - are potentially preventable with Medicaid/PNC on the previous pregnancy. This pitfall also applies to chronic hypertension ("diagnosed prior to onset of pregnancy or before the 20th week of gestation"). The remaining measures have other shortcomings. Specifically, genital herpes may be preventable with prenatal care (ACOG, 1988; Brown, 2000; Brown et al., 2005; CDC, 1989 and 2006; Patel, 2004; Patel and Rompalo, 2005; Rouse and Stringer, 2000); hydramnios/oligohydramnios seems strongly associated with diabetes (Dashe et al., 2000) and so 
its use in a robustness check is limited; and uterine bleeding is very broadly defined. Finally, $\mathrm{Rh}$ sensitization presents a serious danger to the fetus (but not the mother) and mostly occurs during delivery. This may affect how well it is monitored and reported. All in all, we believe diabetes is the best (although imperfect) 'straw man' complication in our data.

${ }^{10}$ In the 1990 s, diabetes was - together with anemia and pregnancy-related hypertension among the three most common complications of pregnancy (CDC 2001). In our sample cohorts, diabetes (including juvenile onset, adult onset, and gestational) tends to be less prevalent than anemia and as prevalent as hypertension (Tables 2 and 3 ).

${ }^{11}$ Briefly, we extract data from the 1988-1996 Behavioral Risk Factor Surveillance System (BRFSS) to create a state-level diabetes rate for each year. We then estimate a series of equations similar to the one written in 'Models Estimated' below that explore the relationships between our maternal diabetes measure, the state-level diabetes rates, and Medicaid eligibility rules. Details and results of these analyses are available upon request.

${ }^{12}$ For example, the passage of PRWORA greatly changed Medicaid eligibility of non-citizens. In particular, prior to year 1996, legal immigrants who otherwise met the Medicaid eligibility requirements were eligible on the same basis as citizens. Therefore, we include non-citizens in our sample. The passage of PRWORA restricted eligibility for most legal immigrants entering the country on or after August 22, 1996 (Accessed 04/10/2006. Available at http://uscis.gov/graphics/aboutus/repsstudies/Tri3Ch4.pdf) 
${ }^{13}$ Sixteen 'medical risk factors' (anemia, cardiac disease, lung disease, diabetes, genital herpes, hydramnios/oligohydramnios, hemoglobinopathy, hypertension chronic and pregnancyassociated, eclampsia, incompetent cervix, previous infant $4000+$ grams, previous preterm or small-for-gestational age infant, renal disease, $\mathrm{Rh}$ sensitization, and uterine bleeding) and fifteen 'complications of labor and/or delivery' (febrile, meconium, premature rupture of membrane, abruption placenta, placenta previa, other excessive bleeding, seizures during labor, precipitous labor, prolonged labor, dysfunctional labor, breech/malpresentation, cephalopelvic disproportion, cord prolapse, anesthetic complication, and fetal distress) are separately identified in the natality fes. Out of these, we focus on conditions that significantly affect maternal health and are known to be preventable by timely and adequate prenatal care. Diabetes serves as a 'straw man'.

${ }^{14}$ Given the complexity of the issue, deriving these measures for our model is beyond the scope of this paper.

15 These data come from the 1989, 1994, and 1996 Green Books and Gil Crouse: "State Implementation of Major Changes to Welfare Policies, 1992 - 1998” (Accessed 06/11/2006. Available at http://aspe.hhs.gov/HSP/Waiver-Policies99/policy_CEA.htm), respectively.

${ }^{16}$ The results from this exercise are available upon request. It is also worth noting that neither of our welfare measures is strongly collinear with Medicaid eligibility. In fact, the state and year dummies included in our models explain about $80 \%$ of the variation in Medicaid eligibility and the welfare measures (caseloads or policy parameters) account only for an additional 1\%. 
${ }^{17} \mathrm{We}$ also re-estimate our main models clustering by state (rather than by state and year). As expected, this modification slightly diminishes statistical significance but otherwise leaves the results qualitatively unchanged.

${ }^{18}$ In a recent report, the CDC also discovers and notes these racial patterns (CDC 2003).

${ }^{19}$ Due to the issues raised by Ai and Norton (2003) and discussed above, we only perform these tests in the OLS models.

${ }^{20}$ Recall that the average incidence of anemia ranges from 1 to $4 \%$ in our samples and so an estimated coefficient or marginal effect of 0.002 , for example, is a relatively large reduction in the average risk.

${ }^{21}$ As noted in section 3, we address the potential concern that our diabetes measure may be spuriously correlated with Medicaid (via state-level trends in the general incidence of diabetes) by adding the state-level diabetes rate as an explanatory variable in our straw man regression. The results are unchanged by this exercise so for consistency with the other models we report the results that omit this variable.

${ }^{22}$ All results not reported here are available upon request.

${ }^{23}$ Racial disparities of a similar sort have been observed elsewhere. For example, Decker and Rapaport (2002) show that becoming eligible for Medicare at the age of 65 increases the chances 
of receiving mammography among low-educated blacks and whites but is associated with improvements in the stage of breast cancer diagnosis only among whites.

${ }^{24}$ Recall the U-shape relationship between maternal age and hypertension noted in the 2003 CDC report. 


\section{List of Tables}

Table 1. Changes in Health Insurance Coverage between 1989 and 1996; 'Treatment Probabilities' from the Current Population Survey

Table 2. Descriptive Statistics; 1989-1996 Births

Table 3. Trends in Prenatal Care Use and Maternal Health

Table 4. The Effects of Medicaid Eligibility Rules on PNC Use and Maternal Health; Coefficients from a Linear Probability Model; 1989-1996

Table 5a. Testing the Effects of Medicaid Eligibility Rules on Maternal Health; Blacks

Table 5b. Testing the Effects of Medicaid Eligibility Rules on Maternal Health; Whites

Table 6. The Effects of Medicaid Eligibility Rules on PNC Use and Maternal Health; Coefficients from a Linear Probability Model; 1989-1996; Primiparous Women

Table 7. Any Complication; Coefficients from a Linear Probability Model; 1989-1996 
Table 1. Changes in Health Insurance Coverage between 1989 and 1996

'Treatment Probabilities' from the Current Population Survey

\begin{tabular}{|c|c|c|c|c|c|c|c|c|c|c|c|}
\hline Race & $\begin{array}{l}\text { Marital } \\
\text { status }\end{array}$ & Education & Cohort & $\begin{array}{l}\text { \# obs. } \\
1989\end{array}$ & $\begin{array}{l}\text { \# obs. } \\
1996\end{array}$ & $\begin{array}{l}\text { \% on } \\
\text { Medicaid } \\
\text { in } 1989\end{array}$ & $\begin{array}{l}\text { \% on } \\
\text { Medicaid } \\
\text { in } 1996\end{array}$ & $\begin{array}{l}\% \text { on } \\
\text { Medicaid } \\
\text { difference }^{\wedge}\end{array}$ & $\begin{array}{l}\text { \% with health } \\
\text { insurance } \\
\text { in } 1989\end{array}$ & $\begin{array}{l}\text { \% with health } \\
\text { insurance } \\
\text { in } 1996\end{array}$ & $\begin{array}{l}\text { \% with health } \\
\text { insurance } \\
\text { difference }\end{array}$ \\
\hline \multirow[t]{8}{*}{ Black } & Married & $\begin{array}{l}\text { Less than high } \\
\text { school }\end{array}$ & TR \#1 & 231 & 105 & 18.01 & 32.37 & 14.36 & 62.28 & 71.78 & 9.50 \\
\hline & Single & $\begin{array}{l}\text { Less than high } \\
\text { school }\end{array}$ & TR \#2 & 584 & 341 & 56.22 & 58.11 & 1.89 & 75.13 & 71.18 & -3.95 \\
\hline & Single & $\begin{array}{l}\text { High school } \\
\text { completed }\end{array}$ & TR \#3 & 1,145 & 915 & 29.89 & 31.11 & 1.22 & 76.08 & 72.09 & -3.99 \\
\hline & Single & Some college & TR \#4 & 619 & 745 & 16.92 & 19.53 & 2.61 & 78.56 & 78.81 & 0.25 \\
\hline & Married & College completed & Control & 217 & 219 & 2.26 & 0.93 & -1.33 & 92.76 & 93.22 & 0.46 \\
\hline & Married & $\begin{array}{l}\text { High school } \\
\text { completed }\end{array}$ & Excluded & 626 & 400 & 7.87 & 7.34 & -0.53 & 82.11 & 76.62 & -5.49 \\
\hline & Married & Some college & Excluded & 322 & 356 & 3.51 & 6.66 & 3.15 & 83.79 & 89.25 & 5.46 \\
\hline & Single & College completed & Excluded & 259 & 250 & 3.33 & 5.54 & 2.21 & 83.26 & 82.62 & -0.64 \\
\hline
\end{tabular}




\begin{tabular}{|c|c|c|c|c|c|c|c|c|c|c|c|}
\hline \multirow[t]{8}{*}{ White } & Married & $\begin{array}{l}\text { Less than high } \\
\text { school }\end{array}$ & TR \#1 & 1,595 & 768 & 10.24 & 17.18 & 6.94 & 69.74 & 72.18 & 2.44 \\
\hline & Single & $\begin{array}{l}\text { Less than high } \\
\text { school }\end{array}$ & TR \#2 & 948 & 551 & 33.06 & 41.92 & 8.86 & 67.73 & 68.67 & 0.94 \\
\hline & Single & $\begin{array}{l}\text { High school } \\
\text { completed }\end{array}$ & TR \#3 & 3,772 & 2,446 & 10.69 & 17.99 & 7.30 & 77.25 & 73.82 & -3.43 \\
\hline & Single & Some college & TR \#4 & 2,839 & 3,018 & 4.83 & 9.26 & 4.43 & 80.52 & 81.32 & 0.80 \\
\hline & Married & College completed & Control & 4,187 & 3,863 & 0.36 & 1.15 & 0.79 & 91.19 & 96.2 & 5.01 \\
\hline & Married & $\begin{array}{l}\text { High school } \\
\text { completed }\end{array}$ & Excluded & 8,001 & 4,856 & 2.47 & 4.41 & 1.94 & 81.87 & 88.26 & 6.39 \\
\hline & Married & Some college & Excluded & 4,089 & 4,120 & 1.16 & 3.04 & 1.88 & 85.88 & 91.86 & 5.98 \\
\hline & Single & College completed & Excluded & 2,249 & 1,961 & 1.28 & 2.14 & 0.86 & 90.34 & 87.65 & -2.69 \\
\hline
\end{tabular}

$\wedge$ We use these estimates as our measure of 'treatment probability.'

‘\% with health insurance' indicates the percentage of women with any health insurance coverage (including Medicaid). 
Table 2. Descriptive Statistics

1989-1996 Births

\begin{tabular}{|c|c|c|c|c|c|c|c|c|c|c|}
\hline & \multicolumn{5}{|c|}{ Blacks } & \multicolumn{5}{|c|}{ Whites } \\
\hline & $\begin{array}{c}\text { Treatment } \\
\text { group \#1 } \\
\text { (less than } \\
\text { high school, } \\
\text { married) }\end{array}$ & $\begin{array}{c}\text { Treatment } \\
\text { group \#2 } \\
\text { (less than } \\
\text { high school, } \\
\text { single) }\end{array}$ & $\begin{array}{c}\text { Treatment } \\
\text { group \#3 } \\
\text { (high school } \\
\text { completed, } \\
\text { single) }\end{array}$ & $\begin{array}{c}\text { Treatment } \\
\text { group \#4 } \\
\text { (some } \\
\text { college, } \\
\text { single) }\end{array}$ & $\begin{array}{c}\text { Control } \\
\text { group } \\
\text { (college } \\
\text { completed, } \\
\text { married) }\end{array}$ & $\begin{array}{c}\text { Treatment } \\
\text { group \#1 } \\
\text { (less than } \\
\text { high school, } \\
\text { married) }\end{array}$ & $\begin{array}{c}\text { Treatment } \\
\text { group \#2 } \\
\text { (less than } \\
\text { high school, } \\
\text { single) }\end{array}$ & $\begin{array}{c}\text { Treatment } \\
\text { group \#3 } \\
\text { (high school } \\
\text { completed, } \\
\text { single) }\end{array}$ & $\begin{array}{c}\text { Treatment } \\
\text { group \#4 } \\
\text { (some } \\
\text { college, } \\
\text { single) }\end{array}$ & $\begin{array}{c}\text { Control } \\
\text { group } \\
\text { (college } \\
\text { completed, } \\
\text { married) }\end{array}$ \\
\hline \# of observations & 134,196 & 619,946 & $1,204,987$ & 495,896 & 278,471 & $1,110,384$ & 723,699 & $1,341,567$ & 533,435 & $4,412,467$ \\
\hline $\begin{array}{l}\text { Placental abruption } \\
\text { (\%) }\end{array}$ & 0.81 & 0.86 & 0.74 & 0.68 & 0.55 & 0.79 & 0.89 & 0.77 & 0.70 & 0.48 \\
\hline Anemia (\%) & 3.49 & 3.86 & 3.41 & 3.21 & 2.48 & 1.93 & 2.23 & 1.86 & 1.80 & 1.14 \\
\hline Hypertension (\%) & 2.45 & 2.04 & 2.80 & 3.33 & 3.62 & 2.47 & 2.29 & 3.35 & 3.70 & 2.95 \\
\hline $\begin{array}{l}\text { Any complication } \\
\text { (\%) }\end{array}$ & 6.56 & 6.56 & 6.73 & 7.02 & 6.48 & 5.08 & 5.27 & 5.84 & 6.06 & 4.49 \\
\hline Diabetes (\%) & 3.21 & 1.54 & 1.83 & 2.23 & 3.51 & 2.57 & 1.92 & 2.15 & 2.33 & 2.34 \\
\hline $\begin{array}{l}\text { PNC in first trimester } \\
(\%)\end{array}$ & 62.51 & 53.11 & 61.70 & 69.07 & 90.18 & 70.86 & 63.46 & 70.37 & 74.35 & 95.15 \\
\hline
\end{tabular}




\begin{tabular}{|c|c|c|c|c|c|c|c|c|c|c|}
\hline $\begin{array}{l}\text { Adequate/intermed. } \\
\text { PNC (\%) }\end{array}$ & 84.21 & 75.47 & 84.50 & 89.55 & 97.59 & 90.22 & 86.94 & 91.40 & 92.67 & 99.04 \\
\hline Age (years) & 27.00 & 24.04 & 24.50 & 25.57 & 30.82 & 24.90 & 23.45 & 24.46 & 25.67 & 31.00 \\
\hline $\begin{array}{l}\text { Parity (\# of live } \\
\text { births) }\end{array}$ & 3.44 & 3.07 & 2.31 & 1.96 & 1.90 & 2.58 & 2.25 & 1.78 & 1.66 & 1.83 \\
\hline Primiparous (\%) & 11.95 & 16.36 & 32.86 & 45.65 & 42.07 & 21.48 & 32.81 & 52.62 & 59.91 & 44.69 \\
\hline Male infant & 50.75 & 50.61 & 50.75 & 50.89 & 50.65 & 51.25 & 51.11 & 51.35 & 51.26 & 51.43 \\
\hline $\begin{array}{l}\text { Medicaid eligibility* } \\
\text { (\% of FPL/100) }\end{array}$ & 1.55 & 1.54 & 1.55 & 1.57 & 1.58 & 1.50 & 1.54 & 1.57 & 1.60 & 1.58 \\
\hline $\begin{array}{l}\text { Welfare caseload* } \\
\text { (\% on welfare) }\end{array}$ & 4.90 & 5.10 & 5.05 & 5.16 & 4.96 & 4.69 & 4.85 & 4.89 & 4.93 & 4.83 \\
\hline Unemployment rate* & 6.35 & 6.30 & 6.25 & 6.30 & 6.20 & 6.13 & 6.13 & 6.09 & 6.09 & 6.07 \\
\hline
\end{tabular}

* Medicaid eligibility, welfare caseload, and unemployment rate are state-level explanatory variables. 


\section{Table 3. Trends in Prenatal Care Use and Maternal Health}

\begin{tabular}{|c|c|c|c|c|c|c|c|c|}
\hline & 1989 & 1990 & 1991 & 1992 & 1993 & 1994 & 1995 & 1996 \\
\hline \multicolumn{9}{|c|}{ Treatment group \#1 (less than high school, married) - Black } \\
\hline PNC in first trimester & 57.92 & 58.26 & 59.90 & 60.89 & 63.52 & 65.95 & 68.60 & 69.63 \\
\hline Placental abruption & 1.06 & 0.73 & 0.73 & 0.77 & 0.74 & 0.82 & 0.78 & 0.89 \\
\hline Anemia & 3.65 & 3.51 & 3.39 & 3.51 & 3.27 & 3.69 & 3.59 & 3.29 \\
\hline Hypertension & 2.55 & 2.36 & 2.32 & 2.12 & 2.27 & 2.57 & 2.72 & 2.97 \\
\hline Diabetes & 2.81 & 2.75 & 2.79 & 3.28 & 3.37 & 3.46 & 3.65 & 3.88 \\
\hline \multicolumn{9}{|c|}{ Treatment group \#2 (less than high school, single) - Black } \\
\hline PNC in first trimester & 48.18 & 48.98 & 50.39 & 51.11 & 53.37 & 56.06 & 57.93 & 59.78 \\
\hline Placental abruption & 0.93 & 0.87 & 0.86 & 0.85 & 0.83 & 0.87 & 0.81 & 0.85 \\
\hline Anemia & 4.16 & 3.91 & 3.61 & 3.47 & 3.61 & 4.05 & 4.06 & 4.13 \\
\hline Hypertension & 2.02 & 1.85 & 1.72 & 1.71 & 1.87 & 2.25 & 2.33 & 2.69 \\
\hline Diabetes & 1.34 & 1.23 & 1.34 & 1.46 & 1.76 & 1.69 & 1.68 & 1.84 \\
\hline \multicolumn{9}{|c|}{ Treatment group \#3 (high school completed, single) - Black } \\
\hline PNC in first trimester & 56.10 & 56.74 & 58.35 & 60.05 & 62.30 & 65.01 & 67.16 & 68.24 \\
\hline Placental abruption & 0.82 & 0.74 & 0.69 & 0.72 & 0.73 & 0.71 & 0.75 & 0.74 \\
\hline Anemia & 3.76 & 3.41 & 3.34 & 3.11 & 3.23 & 3.55 & 3.58 & 3.39 \\
\hline Hypertension & 2.67 & 2.51 & 2.47 & 2.49 & 2.61 & 2.91 & 3.27 & 3.53 \\
\hline Diabetes & 1.41 & 1.40 & 1.60 & 1.87 & 1.93 & 2.08 & 2.08 & 2.18 \\
\hline \multicolumn{9}{|c|}{ Treatment group \#4 (some college, single) - Black } \\
\hline PNC in first trimester & 62.96 & 63.95 & 65.42 & 67.43 & 69.44 & 71.77 & 73.42 & 74.48 \\
\hline Placental abruption & 0.74 & 0.77 & 0.73 & 0.69 & 0.67 & 0.64 & 0.63 & 0.65 \\
\hline Anemia & 3.38 & 3.13 & 3.19 & 2.99 & 3.07 & 3.27 & 3.44 & 3.23 \\
\hline Hypertension & 3.17 & 2.93 & 2.91 & 3.03 & 3.18 & 3.51 & 3.67 & 3.96 \\
\hline Diabetes & 1.78 & 1.71 & 2.02 & 2.21 & 2.43 & 2.30 & 2.45 & 2.61 \\
\hline \multicolumn{9}{|c|}{ Control group (college completed, married) - Black } \\
\hline PNC in first trimester & 88.40 & 89.09 & 89.71 & 89.73 & 90.33 & 90.59 & 91.26 & 91.64 \\
\hline Placental abruption & 0.67 & 0.70 & 0.51 & 0.50 & 0.55 & 0.51 & 0.50 & 0.54 \\
\hline Anemia & 2.67 & 2.51 & 2.35 & 2.35 & 2.50 & 2.36 & 2.66 & 2.49 \\
\hline Hypertension & 3.43 & 3.62 & 3.32 & 3.30 & 3.52 & 3.65 & 3.99 & 3.98 \\
\hline Diabetes & 3.15 & 3.20 & 3.42 & 3.65 & 3.73 & 3.59 & 3.52 & 3.66 \\
\hline
\end{tabular}




\begin{tabular}{|c|c|c|c|c|c|c|c|c|}
\hline \multicolumn{9}{|c|}{ Treatment group \#1 (less than high school, married) - White } \\
\hline PNC in first trimester & 67.30 & 68.24 & 68.89 & 71.07 & 72.21 & 73.46 & 74.29 & 74.49 \\
\hline Placental abruption & 0.84 & 0.80 & 0.77 & 0.80 & 0.75 & 0.77 & 0.78 & 0.79 \\
\hline Anemia & 2.01 & 1.82 & 1.85 & 1.87 & 1.96 & 2.03 & 2.05 & 1.94 \\
\hline Hypertension & 2.28 & 2.23 & 2.24 & 2.33 & 2.51 & 2.58 & 2.87 & 3.07 \\
\hline Diabetes & 2.14 & 2.21 & 2.47 & 2.77 & 2.87 & 2.72 & 2.76 & 2.86 \\
\hline \multicolumn{9}{|c|}{ Treatment group \#2 (less than high school, single) - White } \\
\hline PNC in first trimester & 56.22 & 57.53 & 60.28 & 63.12 & 65.30 & 67.09 & 68.09 & 69.27 \\
\hline Placental abruption & 0.94 & 0.94 & 0.87 & 0.87 & 0.89 & 0.83 & 0.88 & 0.89 \\
\hline Anemia & 2.39 & 2.14 & 2.13 & 2.11 & 2.11 & 2.33 & 2.36 & 2.28 \\
\hline Hypertension & 2.17 & 1.92 & 1.95 & 2.12 & 2.19 & 2.55 & 2.64 & 2.76 \\
\hline Diabetes & 1.53 & 1.57 & 1.77 & 2.12 & 2.08 & 2.08 & 2.04 & 2.08 \\
\hline \multicolumn{9}{|c|}{ Treatment group \#3 (high school completed, single) - White } \\
\hline PNC in first trimester & 63.36 & 64.78 & 66.86 & 69.60 & 71.58 & 73.26 & 74.50 & 75.44 \\
\hline Placental abruption & 0.90 & 0.77 & 0.78 & 0.75 & 0.76 & 0.77 & 0.72 & 0.72 \\
\hline Anemia & 1.81 & 1.70 & 1.75 & 1.83 & 1.78 & 1.97 & 2.02 & 1.98 \\
\hline Hypertension & 3.03 & 2.92 & 2.92 & 3.14 & 3.30 & 3.55 & 3.74 & 3.92 \\
\hline Diabetes & 1.73 & 1.78 & 2.09 & 2.26 & 2.32 & 2.28 & 2.23 & 2.29 \\
\hline \multicolumn{9}{|c|}{ Treatment group \#4 (some college, single) - White } \\
\hline PNC in first trimester & 67.29 & 68.89 & 71.00 & 73.21 & 74.92 & 76.50 & 77.93 & 78.56 \\
\hline Placental abruption & 0.74 & 0.77 & 0.65 & 0.72 & 0.74 & 0.71 & 0.68 & 0.66 \\
\hline Anemia & 1.78 & 1.58 & 1.61 & 1.68 & 1.76 & 1.94 & 1.92 & 1.93 \\
\hline Hypertension & 3.33 & 3.22 & 3.15 & 3.52 & 3.54 & 3.92 & 4.06 & 4.29 \\
\hline Diabetes & 1.92 & 1.92 & 2.35 & 2.52 & 2.45 & 2.40 & 2.35 & 2.46 \\
\hline \multicolumn{9}{|c|}{ Control group (college completed, married) - White } \\
\hline PNC in first trimester & 94.44 & 94.83 & 94.93 & 95.18 & 95.24 & 95.41 & 95.50 & 95.39 \\
\hline Placental abruption & 0.55 & 0.52 & 0.48 & 0.47 & 0.47 & 0.47 & 0.46 & 0.46 \\
\hline Anemia & 0.95 & 0.99 & 1.08 & 1.15 & 1.11 & 1.22 & 1.29 & 1.24 \\
\hline Hypertension & 2.71 & 2.59 & 2.64 & 2.85 & 2.96 & 3.10 & 3.16 & 3.37 \\
\hline Diabetes & 2.19 & 2.19 & 2.36 & 2.63 & 2.46 & 2.34 & 2.23 & 2.31 \\
\hline
\end{tabular}


Table 4. The Effects of Medicaid Eligibility Rules on PNC Use and Maternal Health

Coefficients from a Linear Probability Model; 1989-1996

\begin{tabular}{|c|c|c|c|c|c|c|c|c|}
\hline Cohort & $\begin{array}{l}\text { Treatment } \\
\text { probability }\end{array}$ & $\begin{array}{c}\text { PNC in first } \\
\text { trimester }\end{array}$ & $\begin{array}{l}\text { Adequate/ } \\
\text { Intermed. PNC }\end{array}$ & $\begin{array}{l}\text { Placental } \\
\text { abruption }\end{array}$ & Anemia & Hypertension & $\begin{array}{c}\text { Any } \\
\text { complication }\end{array}$ & Diabetes \\
\hline $\begin{array}{l}\text { Treatment group \#1 } \\
\text { (less than high school, } \\
\text { married) - Black }\end{array}$ & 14.36 & $\begin{array}{l}0.000 \\
(0.04)\end{array}$ & $\begin{array}{l}0.011 \\
(1.43)\end{array}$ & $\begin{array}{l}0.001 \\
(0.74)\end{array}$ & $\begin{array}{l}-0.004 \\
(-1.15)\end{array}$ & $\begin{array}{l}-0.004 \\
(-1.48)\end{array}$ & $\begin{array}{l}-0.009 * \\
(-1.87)\end{array}$ & $\begin{array}{l}0.002 \\
(0.72)\end{array}$ \\
\hline $\begin{array}{l}\text { Treatment group \#2 } \\
\text { (less than high school, } \\
\text { single) - Black }\end{array}$ & 1.89 & $\begin{array}{c}0.040 * * * \\
(4.21)\end{array}$ & $\begin{array}{c}0.033 * * * \\
(4.01)\end{array}$ & $\begin{array}{l}-0.000 \\
(-0.45)\end{array}$ & $\begin{array}{l}-0.005 \\
(-1.28)\end{array}$ & $\begin{array}{l}-0.001 \\
(-0.52)\end{array}$ & $\begin{array}{l}-0.006 \\
(-1.30)\end{array}$ & $\begin{array}{l}-0.001 \\
(-0.88)\end{array}$ \\
\hline $\begin{array}{l}\text { Treatment group \#3 } \\
\text { (high school completed, } \\
\text { single) - Black }\end{array}$ & 1.22 & $\begin{array}{c}0.036 * * * \\
(4.45)\end{array}$ & $\begin{array}{c}0.029 * * * \\
(4.97)\end{array}$ & $\begin{array}{l}-0.000 \\
(-0.04)\end{array}$ & $\begin{array}{l}-0.003 \\
(-1.08)\end{array}$ & $\begin{array}{l}-0.002 \\
(-1.17)\end{array}$ & $\begin{array}{l}-0.004 \\
(-1.25)\end{array}$ & $\begin{array}{l}-0.000 \\
(-0.13)\end{array}$ \\
\hline $\begin{array}{l}\text { Treatment group \#4 } \\
\text { (some college, single) - } \\
\text { Black }\end{array}$ & 2.61 & $\begin{array}{c}0.033 * * * \\
(3.26)\end{array}$ & $\begin{array}{c}0.023 * * * \\
(4.00)\end{array}$ & $\begin{array}{l}-0.001 \\
(-0.90)\end{array}$ & $\begin{array}{l}-0.001 \\
(-0.40)\end{array}$ & $\begin{array}{l}-0.003 \\
(-0.97)\end{array}$ & $\begin{array}{l}-0.004 \\
(-0.94)\end{array}$ & $\begin{array}{l}-0.001 \\
(-0.72)\end{array}$ \\
\hline $\begin{array}{l}\text { Control group } \\
\text { (college completed, } \\
\text { married) - Black }\end{array}$ & -1.33 & $\begin{array}{l}0.004 \\
(0.74)\end{array}$ & $\begin{array}{c}0.005 * * \\
(1.99)\end{array}$ & $\begin{array}{l}-0.001 \\
(-0.95)\end{array}$ & $\begin{array}{l}0.001 \\
(0.52)\end{array}$ & $\begin{array}{l}-0.002 \\
(-0.76)\end{array}$ & $\begin{array}{l}-0.002 \\
(-0.42)\end{array}$ & $\begin{array}{l}-0.000 \\
(-0.11)\end{array}$ \\
\hline $\begin{array}{l}\text { Treatment group \#1 } \\
\text { (less than high school, }\end{array}$ & 6.94 & $\begin{array}{l}0.004 \\
(0.46)\end{array}$ & $\begin{array}{l}0.005 \\
(0.95)\end{array}$ & $\begin{array}{l}0.000 \\
(0.43)\end{array}$ & $\begin{array}{l}-0.002 \\
(-1.25)\end{array}$ & $\begin{array}{c}-0.004 * * * \\
(-3.81)\end{array}$ & $\begin{array}{c}-0.005^{* * *} \\
(-3.27)\end{array}$ & $\begin{array}{l}-0.001 \\
(-0.81)\end{array}$ \\
\hline
\end{tabular}




\begin{tabular}{|c|c|c|c|c|c|c|c|c|}
\hline married) - White & & & & & & & & \\
\hline $\begin{array}{l}\text { Treatment group \#2 } \\
\text { (less than high school, } \\
\text { single) - White }\end{array}$ & 8.86 & $\begin{array}{c}0.032 * * * \\
(3.23)\end{array}$ & $\begin{array}{c}0.022 * * * \\
(3.36)\end{array}$ & $\begin{array}{l}-0.001 \\
(-0.96)\end{array}$ & $\begin{array}{l}-0.002 \\
(-1.33)\end{array}$ & $\begin{array}{l}-0.003 * \\
(-1.88)\end{array}$ & $\begin{array}{c}-0.005 * * \\
(-2.19)\end{array}$ & $\begin{array}{l}0.001 \\
(1.02)\end{array}$ \\
\hline $\begin{array}{l}\text { Treatment group \#3 } \\
\text { (high school completed, } \\
\text { single) - White }\end{array}$ & 7.30 & $\begin{array}{c}0.023 * * * \\
(3.58)\end{array}$ & $\begin{array}{c}0.015 * * * \\
(4.07)\end{array}$ & $\begin{array}{l}0.000 \\
(0.59)\end{array}$ & $\begin{array}{l}-0.001 \\
(-1.10)\end{array}$ & $\begin{array}{l}-0.002 \\
(-1.42)\end{array}$ & $\begin{array}{l}-0.002 \\
(-1.25)\end{array}$ & $\begin{array}{c}0.004 * * * \\
(3.82)\end{array}$ \\
\hline $\begin{array}{l}\text { Treatment group \#4 } \\
\text { (some college, single) - } \\
\text { White }\end{array}$ & 4.43 & $\begin{array}{c}0.024 * * * \\
(3.44)\end{array}$ & $\begin{array}{c}0.012 * * * \\
(2.92)\end{array}$ & $\begin{array}{l}-0.000 \\
(-0.12)\end{array}$ & $\begin{array}{l}-0.001 \\
(-0.98)\end{array}$ & $\begin{array}{l}-0.001 \\
(-0.54)\end{array}$ & $\begin{array}{l}-0.002 \\
(-0.76)\end{array}$ & $\begin{array}{c}0.003 * * \\
(2.27)\end{array}$ \\
\hline $\begin{array}{l}\text { Control group } \\
\text { (college completed, } \\
\text { married) - White }\end{array}$ & 0.79 & $\begin{array}{l}-0.001 \\
(-0.50)\end{array}$ & $\begin{array}{l}-0.001 \\
(-1.52)\end{array}$ & $\begin{array}{l}-0.000 \\
(-0.18)\end{array}$ & $\begin{array}{l}0.000 \\
(0.46)\end{array}$ & $\begin{array}{l}0.000 \\
(0.10)\end{array}$ & $\begin{array}{l}0.000 \\
(0.29)\end{array}$ & $\begin{array}{c}0.002 * * \\
(2.41)\end{array}$ \\
\hline
\end{tabular}

$*, * *$, and $* * *$ denote statistical significance at the $90 \%, 95 \%$, and $99 \%$ confidence levels, respectively.

Standard errors have been adjusted for clustering at the state/year level. T-statistics are given in parentheses.

'Treatment probability' has been calculated from CPS according to the following formula: treatment probability $=\%$ covered by Medicaid in 1996 - \% covered by Medicaid in 1989 .

All coefficients have been compared between treatment and control cohorts. Cells with a difference significant at the $95 \%$ or $99 \%$ confidence level are shaded. Each cell in the table comes from a separate regression. In addition to Medicaid eligibility, our models include state-level welfare caseloads and unemployment rates; a full set of state and year dummies; mother's age, age squared, and parity; and infant gender. Sample size varies by cohort and is reported in Table 2. 
Table 5a. Testing the Effects of Medicaid Eligibility Rules on Maternal Health; BLACKS

\begin{tabular}{|c|c|c|c|c|c|c|c|c|c|c|}
\hline $\begin{array}{l}\text { Incidence (Inc.) or } \\
\mathrm{H}_{0} \wedge\end{array}$ & Inc. & $\mathbf{B}_{\text {prev }}^{\mathrm{t}}=\mathbf{0}$ & $\boldsymbol{\beta}_{\text {prev }}^{\mathrm{t}}-\boldsymbol{\beta}_{\text {prev }}^{\mathrm{c}}=\mathbf{0}$ & $\boldsymbol{\beta}_{\text {prev }}^{\mathrm{t}}-\boldsymbol{\beta}_{\text {diab }}^{\mathrm{t}}=\mathbf{0}$ & $\begin{array}{c}\left(\boldsymbol{\beta}_{\text {prev }}^{\mathrm{t}}-\boldsymbol{\beta}_{\text {diab }}^{\mathrm{t}}\right)- \\
\left(\boldsymbol{\beta}_{\text {prev }}^{\mathrm{c}}-\boldsymbol{\beta}_{\text {diab }}^{\mathrm{c}}\right)=0\end{array}$ & Inc. & $\beta_{\text {prev }}^{\mathrm{t}}=\mathbf{0}$ & $\boldsymbol{\beta}_{\text {prev }}^{\mathrm{t}}-\boldsymbol{\beta}_{\text {prev }}^{\mathrm{c}}=\mathbf{0}$ & $\boldsymbol{\beta}_{\text {prev }}^{\mathrm{t}}-\boldsymbol{\beta}_{\text {diab }}^{\mathrm{t}}=\mathbf{0}$ & $\begin{array}{c}\left(\boldsymbol{\beta}_{\text {prev }}^{\mathrm{t}}-\boldsymbol{\beta}_{\text {diab }}^{\mathrm{t}}\right)^{-} \\
\left(\boldsymbol{B}_{\text {prev }}^{\mathrm{c}}-\boldsymbol{\beta}_{\text {diab }}^{\mathrm{c}}\right)=0\end{array}$ \\
\hline & \multicolumn{5}{|c|}{ Placental abruption } & \multicolumn{5}{|c|}{ Anemia } \\
\hline $\begin{array}{l}\text { Treatment group \#1 } \\
\text { (less than high } \\
\text { school, married) }\end{array}$ & 0.008 & $\begin{array}{c}0.74 \\
-0.002,0.004\end{array}$ & $\begin{array}{c}1.15 \\
-0.002,0.006\end{array}$ & $\begin{array}{c}-0.32 \\
-0.008,0.006\end{array}$ & $\begin{array}{c}-0.09 \\
-0.009,0.009\end{array}$ & 0.035 & $\begin{array}{c}-1.15 \\
-0.012,0.003\end{array}$ & $\begin{array}{c}-1.25 \\
-0.015,0.003\end{array}$ & $\begin{array}{c}-1.34 \\
-0.017,0.003\end{array}$ & $\begin{array}{c}-1.36 \\
-0.021,0.004\end{array}$ \\
\hline $\begin{array}{l}\text { Treatment group \#2 } \\
\text { (less than high } \\
\text { school, single) }\end{array}$ & 0.009 & $\begin{array}{c}-0.45 \\
-0.002,0.001\end{array}$ & $\begin{array}{c}0.44 \\
-0.002,0.003\end{array}$ & $\begin{array}{c}0.45 \\
-0.002,0.004\end{array}$ & $\begin{array}{c}0.49 \\
-0.005,0.008\end{array}$ & 0.039 & $\begin{array}{c}-1.28 \\
-0.012,0.003\end{array}$ & $\begin{array}{c}-1.35 \\
-0.015,0.003\end{array}$ & $\begin{array}{c}-0.93 \\
-0.011,0.004\end{array}$ & $\begin{array}{c}-1.00 \\
-0.016,0.005\end{array}$ \\
\hline $\begin{array}{l}\text { Treatment group \#3 } \\
\text { (high school } \\
\text { completed, single) }\end{array}$ & 0.007 & $\begin{array}{c}-0.04 \\
-0.001,0.001\end{array}$ & $\begin{array}{c}0.84 \\
-0.001,0.003\end{array}$ & $\begin{array}{c}0.10 \\
-0.002,0.003\end{array}$ & $\begin{array}{c}0.31 \\
-0.005,0.007\end{array}$ & 0.034 & $\begin{array}{c}-1.08 \\
-0.008,0.002\end{array}$ & $\begin{array}{c}-1.13 \\
-0.011,0.003\end{array}$ & $\begin{array}{c}-0.94 \\
-0.008,0.003\end{array}$ & $\begin{array}{c}-0.94 \\
-0.013,0.005\end{array}$ \\
\hline \multirow[t]{2}{*}{$\begin{array}{l}\text { Treatment group \#4 } \\
\text { (some college, } \\
\text { single) }\end{array}$} & 0.007 & $\begin{array}{c}-0.90 \\
-0.002,0.001\end{array}$ & $\begin{array}{c}0.19 \\
-0.002,0.003\end{array}$ & $\begin{array}{c}0.18 \\
-0.003,0.004\end{array}$ & $\begin{array}{c}0.34 \\
-0.005,0.007\end{array}$ & 0.032 & $\begin{array}{c}-0.40 \\
-0.006,0.004\end{array}$ & $\begin{array}{c}-0.65 \\
-0.010,0.005\end{array}$ & $\begin{array}{c}0.01 \\
-0.006,0.006\end{array}$ & $\begin{array}{c}-0.34 \\
-0.011,0.008\end{array}$ \\
\hline & \multicolumn{5}{|c|}{ Hypertension } & \multicolumn{5}{|c|}{ Any complication } \\
\hline $\begin{array}{l}\text { Treatment group \#1 } \\
\text { (less than high }\end{array}$ & 0.025 & $\begin{array}{c}-1.48 \\
-0.009,0.001\end{array}$ & $\begin{array}{c}-0.50 \\
-0.009,0.005\end{array}$ & $\begin{array}{c}-1.48 \\
-0.015,0.002\end{array}$ & $\begin{array}{c}-0.82 \\
-0.015,0.006\end{array}$ & 0.066 & $\begin{array}{c}-1.87^{*} \\
-0.017,0.000\end{array}$ & $\begin{array}{c}-1.12 \\
-0.019,0.005\end{array}$ & $\begin{array}{c}-1.93 * \\
-0.022,0.000\end{array}$ & $\begin{array}{c}-1.29 \\
-0.024,0.005\end{array}$ \\
\hline
\end{tabular}




\begin{tabular}{|c|c|c|c|c|c|c|c|c|c|c|}
\hline school, married) & & & & & & & & & & \\
\hline $\begin{array}{l}\text { Treatment group \#2 } \\
\text { (less than high } \\
\text { school, single) }\end{array}$ & 0.020 & $\begin{array}{c}-0.52 \\
-0.005,0.003\end{array}$ & $\begin{array}{c}0.30 \\
-0.005,0.007\end{array}$ & $\begin{array}{c}0.05 \\
-0.004,0.005\end{array}$ & $\begin{array}{c}0.43 \\
-0.007,0.010\end{array}$ & 0.066 & $\begin{array}{c}-1.30 \\
-0.016,0.003\end{array}$ & $\begin{array}{c}-0.73 \\
-0.017,0.008\end{array}$ & $\begin{array}{c}-1.03 \\
-0.015,0.005\end{array}$ & $\begin{array}{c}-0.55 \\
-0.017,0.010\end{array}$ \\
\hline $\begin{array}{l}\text { Treatment group \#3 } \\
\text { (high school } \\
\text { completed, single) }\end{array}$ & 0.028 & $\begin{array}{c}-1.17 \\
-0.005,0.001\end{array}$ & $\begin{array}{c}0.01 \\
-0.006,0.006\end{array}$ & $\begin{array}{c}-0.90 \\
-0.006,0.002\end{array}$ & $\begin{array}{c}-0.02 \\
-0.008,0.008\end{array}$ & 0.067 & $\begin{array}{c}-1.25 \\
-0.011,0.002\end{array}$ & $\begin{array}{c}-0.47 \\
-0.013,0.008\end{array}$ & $\begin{array}{c}-1.14 \\
-0.011,0.003\end{array}$ & $\begin{array}{c}-0.44 \\
-0.014,0.009\end{array}$ \\
\hline $\begin{array}{l}\text { Treatment group \#4 } \\
\text { (some college, } \\
\text { single) }\end{array}$ & 0.033 & $\begin{array}{c}-0.97 \\
-0.008,0.003\end{array}$ & $\begin{array}{c}-0.15 \\
-0.008,0.007\end{array}$ & $\begin{array}{c}-0.48 \\
-0.007,0.005\end{array}$ & $\begin{array}{c}0.06 \\
-0.009,0.009\end{array}$ & 0.070 & $\begin{array}{c}-0.94 \\
-0.012,0.004\end{array}$ & $\begin{array}{c}-0.37 \\
-0.013,0.009\end{array}$ & $\begin{array}{c}-0.63 \\
-0.011,0.006\end{array}$ & $\begin{array}{c}-0.20 \\
-0.014,0.011\end{array}$ \\
\hline
\end{tabular}

Incidence is measured as the number of pregnancies with a recorded maternal complication per one live birth.

${ }^{\wedge}$ In this table, $B$ denotes the effect of Medicaid eligibility on maternal health. ' $t$ ' and ' $c$ ' indicate the treatment group and the control group, respectively. 'prev' stands for a preventable maternal complication and 'diab' for diabetes.

Within each cell testing a hypothesis $\left(\mathrm{H}_{0}\right)$, the first row reports the $\mathrm{t}$ statistic and the second row the $95 \%$ confidence interval. $*$ indicates statistical significance at the $90 \%$ confidence level. 
Table 5b. Testing the Effects of Medicaid Eligibility Rules on Maternal Health; WHITES

\begin{tabular}{|c|c|c|c|c|c|c|c|c|c|c|}
\hline $\begin{array}{l}\text { Incidence (Inc.) or } \\
\mathrm{H}_{\mathbf{0}} \wedge\end{array}$ & Inc. & $\mathrm{B}_{\text {prev }}^{\mathrm{t}}=\mathbf{0}$ & $\boldsymbol{B}_{\text {prev }}^{\mathrm{t}} \boldsymbol{-}_{\text {prev }}^{\mathrm{C}}=\mathbf{0}$ & $\mathbf{B}_{\text {prev }}^{\mathrm{t}}-\boldsymbol{\beta}_{\text {diab }}^{\mathrm{t}}=\mathbf{0}$ & $\begin{array}{c}\left(\AA_{\text {prev }}^{\mathrm{t}}-\AA_{\text {diab }}^{\mathrm{t}}\right)^{-} \\
\left(\boldsymbol{\beta}_{\text {prev }}^{\mathrm{c}}-\boldsymbol{\beta}_{\text {diab }}^{\mathrm{c}}\right)=0\end{array}$ & Inc. & $\mathbf{B}_{\text {prev }}^{\mathrm{t}}=\mathbf{0}$ & $\boldsymbol{\beta}_{\text {prev }}^{\mathrm{t}}-\boldsymbol{\beta}_{\text {prev }}^{\mathrm{C}}=\mathbf{0}$ & $\mathbf{B}_{\text {prev }}^{\mathrm{t}}-\boldsymbol{\beta}_{\text {diab }}^{\mathrm{t}}=\mathbf{0}$ & $\begin{array}{c}\left(\boldsymbol{\beta}_{\text {prev }}^{\mathrm{t}}-\boldsymbol{\beta}_{\text {diab }}^{\mathrm{t}}\right)^{-} \\
\left(\boldsymbol{\beta}_{\text {prev }}^{\mathrm{c}}-\boldsymbol{\beta}_{\text {diab }}^{\mathrm{c}}\right)=0\end{array}$ \\
\hline & \multicolumn{5}{|c|}{ Placental abruption } & \multicolumn{5}{|c|}{ Anemia } \\
\hline $\begin{array}{l}\text { Treatment group \#1 } \\
\text { (less than high } \\
\text { school, married) }\end{array}$ & 0.008 & $\begin{array}{c}0.43 \\
-0.001,0.001\end{array}$ & $\begin{array}{c}0.45 \\
-0.001,0.002\end{array}$ & $\begin{array}{c}0.91 \\
-0.001,0.003\end{array}$ & $\begin{array}{c}2.23 * * \\
0.000,0.007\end{array}$ & 0.019 & $\begin{array}{c}-1.25 \\
-0.004,0.001\end{array}$ & $\begin{array}{c}-1.27 \\
-0.005,0.001\end{array}$ & $\begin{array}{c}-0.43 \\
-0.004,0.002\end{array}$ & $\begin{array}{c}0.62 \\
-0.003,0.005\end{array}$ \\
\hline $\begin{array}{l}\text { Treatment group \#2 } \\
\text { (less than high } \\
\text { school, single) }\end{array}$ & 0.009 & $\begin{array}{c}-0.96 \\
-0.002,0.001\end{array}$ & $\begin{array}{c}-0.77 \\
-0.002,0.001\end{array}$ & $\begin{array}{c}-1.38 \\
-0.005,0.001\end{array}$ & $\begin{array}{c}0.32 \\
-0.003,0.004\end{array}$ & 0.022 & $\begin{array}{c}-1.33 \\
-0.005,0.001\end{array}$ & $\begin{array}{c}-1.39 \\
-0.006,0.001\end{array}$ & $\begin{array}{c}-1.67^{*} \\
-0.007,0.001\end{array}$ & $\begin{array}{c}-0.57 \\
-0.006,0.003\end{array}$ \\
\hline $\begin{array}{l}\text { Treatment group \#3 } \\
\text { (high school } \\
\text { completed, single) }\end{array}$ & 0.008 & $\begin{array}{c}0.59 \\
-0.001,0.001\end{array}$ & $\begin{array}{c}0.56 \\
-0.001,0.002\end{array}$ & $\begin{array}{c}-3.17 * * * \\
-0.005,-0.001\end{array}$ & $\begin{array}{c}-0.55 \\
-0.004,0.002\end{array}$ & 0.019 & $\begin{array}{c}-1.10 \\
-0.004,0.001\end{array}$ & $\begin{array}{c}-1.15 \\
-0.005,0.001\end{array}$ & $\begin{array}{c}-3.26^{* * *} \\
-0.008,-0.002\end{array}$ & $\begin{array}{c}-1.43 \\
-0.007,0.001\end{array}$ \\
\hline \multirow[t]{2}{*}{$\begin{array}{l}\text { Treatment group \#4 } \\
\text { (some college, } \\
\text { single) }\end{array}$} & 0.007 & $\begin{array}{c}-0.12 \\
-0.002,0.001\end{array}$ & $\begin{array}{c}-0.01 \\
-0.002,0.002\end{array}$ & $\begin{array}{c}-2.06^{* *} \\
-0.006,0.000\end{array}$ & $\begin{array}{c}-0.41 \\
-0.005,0.003\end{array}$ & 0.018 & $\begin{array}{c}-0.98 \\
-0.004,0.001\end{array}$ & $\begin{array}{c}-1.07 \\
-0.005,0.002\end{array}$ & $\begin{array}{c}-2.29 * * \\
-0.009,-0.001\end{array}$ & $\begin{array}{c}-1.07 \\
-0.007,0.002\end{array}$ \\
\hline & \multicolumn{5}{|c|}{ Hypertension } & \multicolumn{5}{|c|}{ Any complication } \\
\hline $\begin{array}{l}\text { Treatment group \#1 } \\
\text { (less than high } \\
\text { school, married) }\end{array}$ & 0.025 & $\begin{array}{c}-3.81^{* * *} \\
-0.006,-0.002\end{array}$ & $\begin{array}{c}-2.61 * * * \\
-0.007,-0.001\end{array}$ & $\begin{array}{c}-2.11 * * \\
-0.006,0.000\end{array}$ & $\begin{array}{c}-0.37 \\
-0.005,0.003\end{array}$ & 0.051 & $\begin{array}{c}-3.27^{* * *} \\
-0.009,-0.002\end{array}$ & $\begin{array}{c}-2.56^{* *} \\
-0.010,-0.001\end{array}$ & $\begin{array}{c}-2.34 * * \\
-0.008,-0.001\end{array}$ & $\begin{array}{c}-0.96 \\
-0.008,0.003\end{array}$ \\
\hline
\end{tabular}


65

\begin{tabular}{|c|c|c|c|c|c|c|c|c|c|c|}
\hline $\begin{array}{l}\text { Treatment group \#2 } \\
\text { (less than high } \\
\text { school, single) }\end{array}$ & 0.023 & $\begin{array}{c}-1.88^{*} \\
-0.005,0.000\end{array}$ & $\begin{array}{c}-1.50 \\
-0.006,0.001\end{array}$ & $\begin{array}{c}-2.09^{* *} \\
-0.007,0.000\end{array}$ & $\begin{array}{c}-0.61 \\
-0.006,0.003\end{array}$ & 0.053 & $\begin{array}{c}-2.19^{* *} \\
-0.010,-0.001\end{array}$ & $\begin{array}{c}-1.99^{* *} \\
-0.011,0.000\end{array}$ & $\begin{array}{c}-2.41^{* *} \\
-0.012,-0.001\end{array}$ & $\begin{array}{c}-1.38 \\
-0.011,0.002\end{array}$ \\
\hline $\begin{array}{l}\text { Treatment group \#3 } \\
\text { (high school } \\
\text { completed, single) }\end{array}$ & 0.034 & $\begin{array}{c}-1.42 \\
-0.004,0.001\end{array}$ & $\begin{array}{c}-1.06 \\
-0.005,0.001\end{array}$ & $\begin{array}{c}-3.53^{* * *} \\
-0.008,-0.002\end{array}$ & $\begin{array}{c}-1.36 \\
-0.007,0.001\end{array}$ & 0.058 & $\begin{array}{c}-1.25 \\
-0.006,0.001\end{array}$ & $\begin{array}{c}-1.13 \\
-0.007,0.002\end{array}$ & $\begin{array}{c}-2.90^{* * *} \\
-0.010,-0.002\end{array}$ & $\begin{array}{c}-1.40 \\
-0.009,0.002\end{array}$ \\
\hline $\begin{array}{l}\text { Treatment group \#4 } \\
\text { (some college, } \\
\text { single) }\end{array}$ & 0.037 & $\begin{array}{c}-0.54 \\
-0.005,0.003\end{array}$ & $\begin{array}{c}-0.51 \\
-0.005,0.003\end{array}$ & $\begin{array}{c}-1.81^{*} \\
-0.009,0.000\end{array}$ & $\begin{array}{c}-0.68 \\
-0.007,0.004\end{array}$ & 0.061 & $\begin{array}{c}-0.76 \\
-0.007,0.003\end{array}$ & $\begin{array}{c}-0.80 \\
-0.008,0.003\end{array}$ & $\begin{array}{c}-1.77^{*} \\
-0.011,0.001\end{array}$ & $\begin{array}{c}-0.91 \\
-0.010,0.004\end{array}$ \\
\hline
\end{tabular}

Incidence is measured as the number of pregnancies with a recorded maternal complication per one live birth.

${ }^{\wedge}$ In this table, $\beta$ denotes the effect of Medicaid eligibility on maternal health. ' $t$ ' and ' $c$ ' indicate the treatment group and the control group, respectively. 'prev' stands for a preventable maternal complication and 'diab' for diabetes.

Within each cell testing a hypothesis $\left(\mathrm{H}_{0}\right)$, the first row reports the $\mathrm{t}$ statistic and the second row the $95 \%$ confidence interval. * ${ }^{* *}$, and ${ }^{* * *}$ indicate statistical significance at the $90 \%, 95 \%$, and $99 \%$ confidence levels, respectively. 
Table 6. The Effects of Medicaid Eligibility Rules on PNC Use and Maternal Health Coefficients from a Linear Probability Model; 1989-1996; PRIMIPAROUS WOMEN

\begin{tabular}{|c|c|c|c|c|c|c|c|c|}
\hline Cohort & $\begin{array}{l}\text { Treatment } \\
\text { probability }\end{array}$ & $\begin{array}{c}\text { PNC in first } \\
\text { trimester }\end{array}$ & $\begin{array}{l}\text { Adequate/ } \\
\text { Intermed. PNC }\end{array}$ & $\begin{array}{l}\text { Placental } \\
\text { abruption }\end{array}$ & Anemia & Hypertension & $\begin{array}{c}\text { Any } \\
\text { complication }\end{array}$ & Diabetes \\
\hline $\begin{array}{l}\text { Treatment group \#1 } \\
\text { (less than high school, } \\
\text { married) - Black }\end{array}$ & 14.36 & $\begin{array}{l}0.002 \\
(0.08)\end{array}$ & $\begin{array}{l}-0.012 \\
(-0.83)\end{array}$ & $\begin{array}{l}0.005 \\
(1.13)\end{array}$ & $\begin{array}{l}-0.005 \\
(-0.60)\end{array}$ & $\begin{array}{l}0.000 \\
(0.01)\end{array}$ & $\begin{array}{l}0.003 \\
(0.21)\end{array}$ & $\begin{array}{l}0.009 \\
(0.95)\end{array}$ \\
\hline $\begin{array}{l}\text { Treatment group \#2 } \\
\text { (less than high school, } \\
\text { single) - Black }\end{array}$ & 1.89 & $\begin{array}{l}0.022 \\
(1.61)\end{array}$ & $\begin{array}{l}0.017^{*} \\
(1.72)\end{array}$ & $\begin{array}{l}0.001 \\
(0.61)\end{array}$ & $\begin{array}{l}-0.008 * \\
(-1.95)\end{array}$ & $\begin{array}{l}0.004 \\
(0.80)\end{array}$ & $\begin{array}{l}-0.003 \\
(-0.40)\end{array}$ & $\begin{array}{l}-0.004 \\
(-1.35)\end{array}$ \\
\hline $\begin{array}{l}\text { Treatment group \#3 } \\
\text { (high school completed, } \\
\text { single) - Black }\end{array}$ & 1.22 & $\begin{array}{c}0.023 * * * \\
(2.87)\end{array}$ & $\begin{array}{c}0.014 * * * \\
(2.82)\end{array}$ & $\begin{array}{l}0.000 \\
(0.52)\end{array}$ & $\begin{array}{l}0.000 \\
(0.14)\end{array}$ & $\begin{array}{c}-0.008 * * \\
(-2.53)\end{array}$ & $\begin{array}{l}-0.006 \\
(-1.61)\end{array}$ & $\begin{array}{l}-0.002 \\
(-1.44)\end{array}$ \\
\hline $\begin{array}{l}\text { Treatment group \#4 } \\
\text { (some college, single) - } \\
\text { Black }\end{array}$ & 2.61 & $\begin{array}{c}0.033 * * * \\
(3.43)\end{array}$ & $\begin{array}{c}0.016 * * * \\
(3.08)\end{array}$ & $\begin{array}{l}-0.000 \\
(-0.39)\end{array}$ & $\begin{array}{l}-0.002 \\
(-0.56)\end{array}$ & $\begin{array}{l}-0.006 \\
(-1.48)\end{array}$ & $\begin{array}{l}-0.007 \\
(-1.38)\end{array}$ & $\begin{array}{l}-0.003 \\
(-1.39)\end{array}$ \\
\hline $\begin{array}{l}\text { Control group } \\
\text { (college completed, } \\
\text { married) - Black }\end{array}$ & -1.33 & $\begin{array}{l}0.003 \\
(0.51)\end{array}$ & $\begin{array}{l}0.004 \\
(1.50)\end{array}$ & $\begin{array}{l}-0.001 \\
(-0.51)\end{array}$ & $\begin{array}{l}0.003 \\
(0.80)\end{array}$ & $\begin{array}{l}-0.003 \\
(-0.78)\end{array}$ & $\begin{array}{l}-0.001 \\
(-0.09)\end{array}$ & $\begin{array}{l}-0.001 \\
(-0.19)\end{array}$ \\
\hline $\begin{array}{l}\text { Treatment group \#1 } \\
\text { (less than high school, } \\
\text { married) - White }\end{array}$ & 6.94 & $\begin{array}{l}0.001 \\
(0.10)\end{array}$ & $\begin{array}{l}-0.001 \\
(-0.17)\end{array}$ & $\begin{array}{l}0.002 * \\
(1.88)\end{array}$ & $\begin{array}{l}-0.002 \\
(-1.12)\end{array}$ & $\begin{array}{c}-0.007 * * \\
(-2.39)\end{array}$ & $\begin{array}{l}-0.006^{*} \\
(-1.89)\end{array}$ & $\begin{array}{l}-0.002 \\
(-0.80)\end{array}$ \\
\hline
\end{tabular}




\begin{tabular}{|c|c|c|c|c|c|c|c|c|}
\hline $\begin{array}{l}\text { Treatment group \#2 } \\
\text { (less than high school, } \\
\text { single) - White }\end{array}$ & 8.86 & $\begin{array}{c}0.027 * * \\
(2.59)\end{array}$ & $\begin{array}{c}0.017 * * * \\
(2.98)\end{array}$ & $\begin{array}{l}-0.001 \\
(-0.80)\end{array}$ & $\begin{array}{l}-0.001 \\
(-0.51)\end{array}$ & $\begin{array}{c}-0.007 * * * b \\
(-2.76)\end{array}$ & $\begin{array}{c}-0.008 * * \mathrm{~b} \\
(-2.14)\end{array}$ & $\begin{array}{l}0.001 \\
(0.46)\end{array}$ \\
\hline $\begin{array}{l}\text { Treatment group \#3 } \\
\text { (high school completed, } \\
\text { single) - White }\end{array}$ & 7.30 & $\begin{array}{c}0.019 * * * \\
(2.94)\end{array}$ & $\begin{array}{c}0.013 * * * \\
(3.78)\end{array}$ & $\begin{array}{l}0.000^{\mathrm{b}} \\
(0.81)\end{array}$ & $\begin{array}{l}-0.002^{\mathrm{c}} \\
(-1.61)\end{array}$ & $\begin{array}{l}-0.002^{\mathrm{c}} \\
(-1.37)\end{array}$ & $\begin{array}{c}-0.004 * \mathrm{c} \\
(-1.76)\end{array}$ & $\begin{array}{c}0.004^{* * *} \\
(3.19)\end{array}$ \\
\hline $\begin{array}{l}\text { Treatment group \#4 } \\
\text { (some college, single) - } \\
\text { White }\end{array}$ & 4.43 & $\begin{array}{c}0.018 * * \\
(2.50)\end{array}$ & $\begin{array}{c}0.010 * * \\
(2.52)\end{array}$ & $\begin{array}{l}-0.000^{b} \\
(-0.07)\end{array}$ & $\begin{array}{l}0.000^{\mathrm{a}} \\
(0.15)\end{array}$ & $\begin{array}{l}-0.001^{\mathrm{a}} \\
(-0.37)\end{array}$ & $\begin{array}{l}-0.000 \\
(-0.06)\end{array}$ & $\begin{array}{c}0.005 * * * \\
(2.76)\end{array}$ \\
\hline $\begin{array}{l}\text { Control group } \\
\text { (college completed, } \\
\text { married) - White }\end{array}$ & 0.79 & $\begin{array}{l}-0.000 \\
(-0.08)\end{array}$ & $\begin{array}{l}-0.001 \\
(-0.69)\end{array}$ & $\begin{array}{c}0.000^{b} \\
(0.57)\end{array}$ & $\begin{array}{l}0.001 \\
(0.74)\end{array}$ & $\begin{array}{c}-0.003^{b} \\
(-1.31)\end{array}$ & $\begin{array}{r}-0.001^{\mathrm{a}} \\
(-0.63)\end{array}$ & $\begin{array}{c}0.003 * * * \\
(2.62)\end{array}$ \\
\hline
\end{tabular}

$*, * *$, and $* * *$ denote statistical significance at the $90 \%, 95 \%$, and $99 \%$ confidence levels, respectively.

Standard errors have been adjusted for clustering at the state/year level. T-statistics are given in parentheses.

'Treatment probability' has been calculated as in Table 4 above.

All coefficients have been compared between treatment and control cohorts. Cells with a difference significant at the $95 \%$ or $99 \%$ confidence level are shaded. Coefficients on placental abruption, anemia, hypertension, and 'any complication' have been compared to coefficients on diabetes within cohorts. ${ }^{\mathbf{a}},{ }^{\mathbf{b}},{ }^{\text {and }}{ }^{\mathbf{c}}$ indicate differences statistically significance at the $90 \%, 95 \%$, and $99 \%$ confidence levels, respectively.

Each cell in the table comes from a separate regression. In addition to Medicaid eligibility, our models include state-level welfare caseloads and unemployment rates; a full set of state and year dummies; mother's age and age squared; and infant gender. Sample size varies by cohort and is reported in Table 2. 
Table 7. Any Complication

Coefficients from a Linear Probability Model; 1989-1996

\begin{tabular}{|c|c|c|c|c|c|c|c|c|c|c|}
\hline & \multicolumn{5}{|c|}{ Blacks } & \multicolumn{5}{|c|}{ Whites } \\
\hline & $\begin{array}{l}\text { Treatment } \\
\text { group \#1 } \\
\text { (less than } \\
\text { high school, } \\
\text { married) }\end{array}$ & $\begin{array}{c}\text { Treatment } \\
\text { group \#2 } \\
\text { (less than } \\
\text { high school, } \\
\text { single) }\end{array}$ & $\begin{array}{c}\text { Treatment } \\
\text { group \#3 } \\
\text { (high school } \\
\text { completed, } \\
\text { single) }\end{array}$ & $\begin{array}{c}\text { Treatment } \\
\text { group \#4 } \\
\text { (some } \\
\text { college, } \\
\text { single) }\end{array}$ & $\begin{array}{c}\text { Control } \\
\text { group } \\
\text { (college } \\
\text { completed, } \\
\text { married) }\end{array}$ & $\begin{array}{l}\text { Treatment } \\
\text { group \#1 } \\
\text { (less than } \\
\text { high school, } \\
\text { married) }\end{array}$ & $\begin{array}{c}\text { Treatment } \\
\text { group \#2 } \\
\text { (less than } \\
\text { high school, } \\
\text { single) }\end{array}$ & $\begin{array}{c}\text { Treatment } \\
\text { group \#3 } \\
\text { (high school } \\
\text { completed, } \\
\text { single) }\end{array}$ & $\begin{array}{c}\text { Treatment } \\
\text { group \#4 } \\
\text { (some } \\
\text { college, } \\
\text { single) }\end{array}$ & $\begin{array}{c}\text { Control } \\
\text { group } \\
\text { (college } \\
\text { completed, } \\
\text { married) }\end{array}$ \\
\hline Medicaid eligibility & $\begin{array}{l}-0.009 * \\
(-1.87)\end{array}$ & $\begin{array}{l}-0.006 \\
(-1.30)\end{array}$ & $\begin{array}{l}-0.004 \\
(-1.25)\end{array}$ & $\begin{array}{l}-0.004 \\
(-0.94)\end{array}$ & $\begin{array}{l}-0.002 \\
(-0.42)\end{array}$ & $\begin{array}{c}-0.005 * * * \\
(-3.27)\end{array}$ & $\begin{array}{c}-0.005 * * \\
(-2.19)\end{array}$ & $\begin{array}{l}-0.002 \\
(-1.25)\end{array}$ & $\begin{array}{l}-0.002 \\
(-0.76)\end{array}$ & $\begin{array}{l}0.000 \\
(0.29)\end{array}$ \\
\hline Welfare caseload & $\begin{array}{l}-0.000 \\
(-0.12)\end{array}$ & $\begin{array}{l}-0.002 \\
(-0.86)\end{array}$ & $\begin{array}{l}-0.003 \\
(-1.23)\end{array}$ & $\begin{array}{c}-0.004^{*} \\
(-1.81)\end{array}$ & $\begin{array}{l}-0.003 \\
(-1.25)\end{array}$ & $\begin{array}{c}0.002 * * \\
(2.22)\end{array}$ & $\begin{array}{l}-0.001 \\
(-0.79)\end{array}$ & $\begin{array}{l}0.001 \\
(1.63)\end{array}$ & $\begin{array}{c}0.003 * * * \\
(2.88)\end{array}$ & $\begin{array}{l}0.000 \\
(0.61)\end{array}$ \\
\hline Unemployment rate & $\begin{array}{l}0.000 \\
(0.02)\end{array}$ & $\begin{array}{l}0.000 \\
(0.11)\end{array}$ & $\begin{array}{l}0.000 \\
(0.31)\end{array}$ & $\begin{array}{l}0.001 \\
(0.89)\end{array}$ & $\begin{array}{l}0.001 \\
(0.64)\end{array}$ & $\begin{array}{l}-0.000 \\
(-0.13)\end{array}$ & $\begin{array}{l}0.000 \\
(0.74)\end{array}$ & $\begin{array}{l}0.000 \\
(0.44)\end{array}$ & $\begin{array}{l}-0.001 \\
(-1.19)\end{array}$ & $\begin{array}{l}-0.000 \\
(-0.11)\end{array}$ \\
\hline Age & $\begin{array}{c}-0.009 * * * \\
(-8.30)\end{array}$ & $\begin{array}{c}-0.006 * * * \\
(-9.68)\end{array}$ & $\begin{array}{c}-0.007 * * * \\
(-14.24)\end{array}$ & $\begin{array}{c}-0.003 * * * \\
(-4.68)\end{array}$ & $\begin{array}{c}-0.009 * * * \\
(-7.57)\end{array}$ & $\begin{array}{c}-0.007 * * * \\
(-16.03)\end{array}$ & $\begin{array}{c}-0.007 * * * \\
(-11.53)\end{array}$ & $\begin{array}{c}-0.007 * * * \\
(-15.07)\end{array}$ & $\begin{array}{c}-0.005 * * * \\
(-9.65)\end{array}$ & $\begin{array}{c}-0.012 * * * \\
(-18.80)\end{array}$ \\
\hline Age squared & $\begin{array}{c}0.000 * * * \\
(8.44)\end{array}$ & $\begin{array}{c}0.000 * * * \\
(9.31)\end{array}$ & $\begin{array}{c}0.000 * * * \\
(14.51)\end{array}$ & $\begin{array}{c}0.000 * * * \\
(5.50)\end{array}$ & $\begin{array}{c}0.000 * * * \\
(8.39)\end{array}$ & $\begin{array}{c}0.000 * * * \\
(17.64)\end{array}$ & $\begin{array}{c}0.000 * * * \\
(12.37)\end{array}$ & $\begin{array}{c}0.000 * * * \\
(16.05)\end{array}$ & $\begin{array}{c}0.000 * * * \\
(10.77)\end{array}$ & $\begin{array}{c}0.000 * * * \\
(19.68)\end{array}$ \\
\hline
\end{tabular}




\begin{tabular}{|c|c|c|c|c|c|c|c|c|c|c|}
\hline Parity & $\begin{array}{l}0.001 \\
(1.57)\end{array}$ & $\begin{array}{l}0.001 \\
(1.57)\end{array}$ & $\begin{array}{c}-0.002 * * * \\
(-5.58)\end{array}$ & $\begin{array}{c}-0.003 * * * \\
(-6.80)\end{array}$ & $\begin{array}{c}-0.007 * * * \\
(-11.87)\end{array}$ & $\begin{array}{c}-0.004 * * * \\
(-19.27)\end{array}$ & $\begin{array}{c}-0.003 * * * \\
(-11.07)\end{array}$ & $\begin{array}{c}-0.007 * * * \\
(-23.70)\end{array}$ & $\begin{array}{c}-0.007 * * * \\
(-15.94)\end{array}$ & $\begin{array}{c}-0.011 * * * \\
(-35.49)\end{array}$ \\
\hline Male infant & $\begin{array}{l}-0.002 \\
(-1.29)\end{array}$ & $\begin{array}{c}-0.002 * * * \\
(-3.46)\end{array}$ & $\begin{array}{c}-0.001 * * * \\
(-2.82)\end{array}$ & $\begin{array}{c}-0.002 * * * \\
(-3.15)\end{array}$ & $\begin{array}{c}-0.002 * * * \\
(-2.66)\end{array}$ & $\begin{array}{c}0.002 * * * \\
(3.83)\end{array}$ & $\begin{array}{c}0.002 * * * \\
(3.87)\end{array}$ & $\begin{array}{c}0.003 * * * \\
(7.05)\end{array}$ & $\begin{array}{c}0.002 * * \\
(2.43)\end{array}$ & $\begin{array}{c}0.001 * * \\
(2.13)\end{array}$ \\
\hline
\end{tabular}

$*, * *$, and $* * *$ denote statistical significance at the $90 \%, 95 \%$, and $99 \%$ confidence levels, respectively.

Standard errors have been adjusted for clustering at the state/year level. T-statistics are given in parentheses.

Sample size varies by cohort and is reported in Table 2 . 


\section{List of Figures}

Figure 1. Medicaid Eligibility Threshold, 1988-1996; Minimum, Maximum, and Average

Figure 2. Medicaid Eligibility Threshold, 1988-1996; Five Largest States 


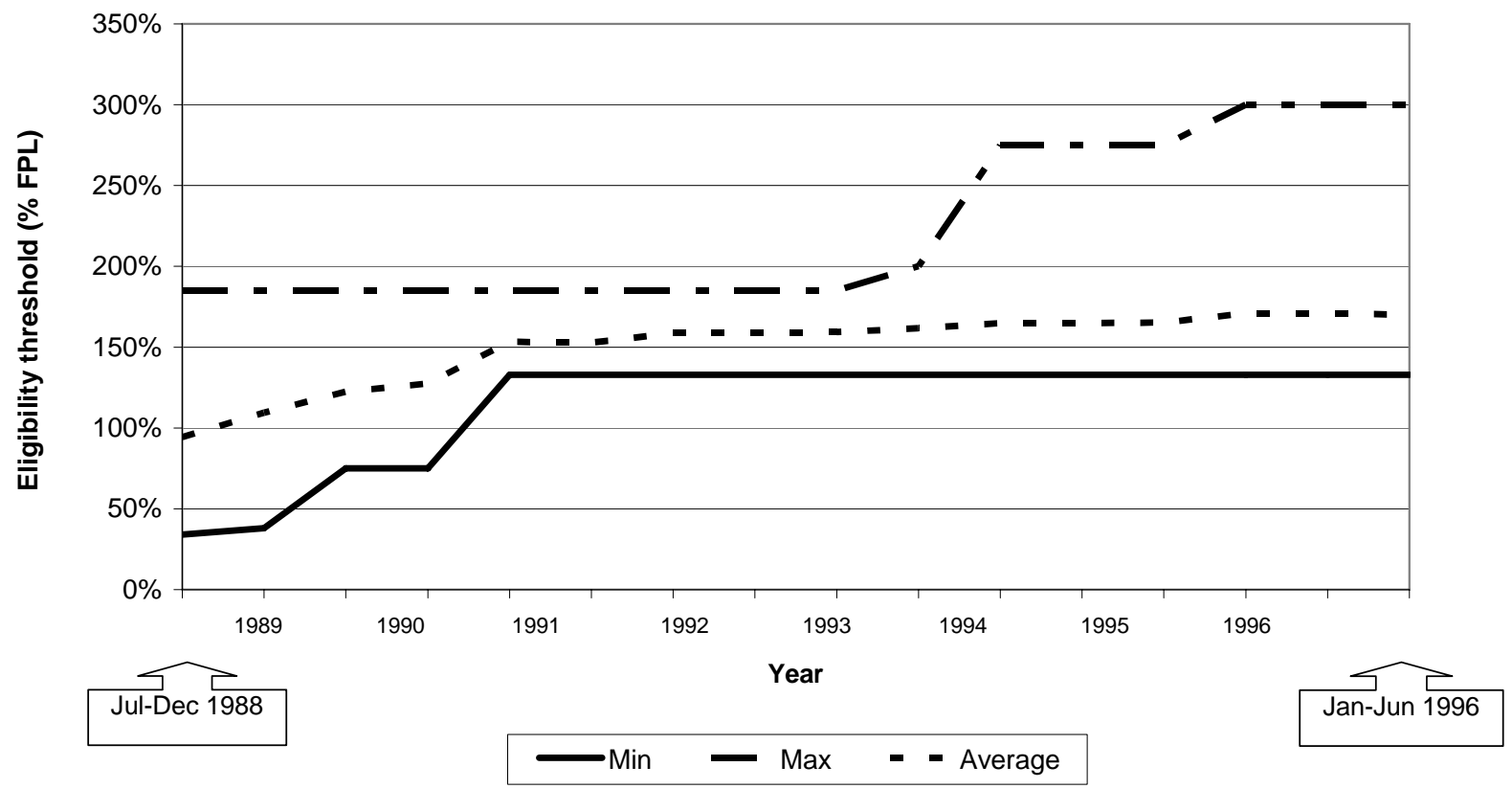




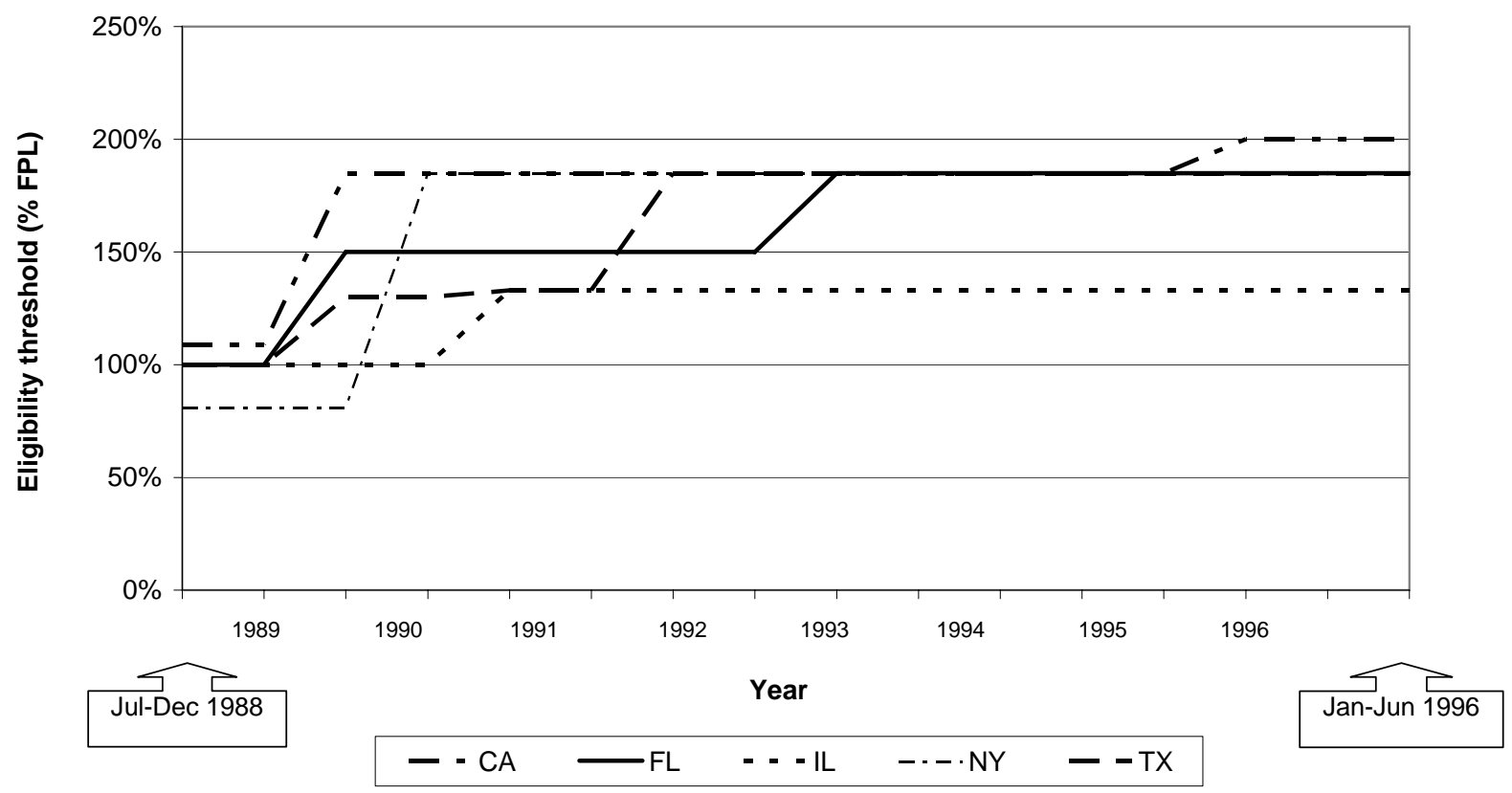

